San Jose State University

SJSU ScholarWorks

Master's Theses

Master's Theses and Graduate Research

Spring 2016

\title{
A Sedimentological Analysis of the Siliciclastic Fraction in Pliocene Core Sediments from Bowers Ridge, Bering Sea (IODP Exp 323)
}

Melinda Tanner

San Jose State University

Follow this and additional works at: https://scholarworks.sjsu.edu/etd_theses

\section{Recommended Citation}

Tanner, Melinda, "A Sedimentological Analysis of the Siliciclastic Fraction in Pliocene Core Sediments from Bowers Ridge, Bering Sea (IODP Exp 323)" (2016). Master's Theses. 4709.

DOI: https://doi.org/10.31979/etd.2zaj-y96t

https://scholarworks.sjsu.edu/etd_theses/4709

This Thesis is brought to you for free and open access by the Master's Theses and Graduate Research at SJSU ScholarWorks. It has been accepted for inclusion in Master's Theses by an authorized administrator of SJSU ScholarWorks. For more information, please contact scholarworks@sjsu.edu. 


\title{
A SEDIMENTOLOGICAL ANALYSIS OF THE SILICICLASTIC FRACTION IN PLIOCENE CORE SEDIMENTS FROM BOWERS RIDGE, BERING SEA (IODP EXP 323)
}

\author{
A Thesis \\ Presented to \\ The Faculty of the Department of Marine Science \\ San José State University \\ In Partial Fulfillment \\ of the Requirements for the Degree \\ Master of Science
}

by

Melinda J. Tanner

May 2016 
(C) 2016

Melinda J. Tanner

ALL RIGHTS RESERVED 
The Designated Thesis Committee Approves the Thesis Titled

\section{A SEDIMENTOLOGICAL ANALYSIS OF THE SILICICLASTIC FRACTION IN \\ PLIOCENE CORE SEDIMENTS FROM BOWERS RIDGE, BERING SEA (IODP EXP 323)}

by

Melinda J. Tanner

APPROVED FOR THE DEPARTMENT OF MARINE SCIENCE

SAN JOSE STATÉ UNIVERSITY

May 2016

Dr. Ivano Aiello

Department of Marine Science, Moss

Landing Marine Laboratories

Dr. Kenneth Coale

Department of Marine Science, Moss

Landing Marine Laboratories

Dr. Ana Christina Ravelo

Department of Ocean Sciences, University of California, Santa Cruz 


\title{
ABSTRACT \\ A SEDIMENTOLOGICAL ANALYSIS OF THE SILICICLASTIC FRACTION IN PLIOCENE CORE SEDIMENTS FROM BOWERS RIDGE, BERING SEA (IODP EXP 323)
}

\author{
by Melinda J. Tanner
}

The analysis and interpretation of sediment cores constitutes an important data record that can be used to evaluate paleoclimatic conditions and changes over time. The causes for the cooling trend that began in the Eocene, and its intensification with the onset of North Hemisphere Glaciation (NHG), remain under debate. Using sediment core samples from Site U1341 in the Bering Sea, the principal goal of this thesis was to examine the record at 1.9-4.2 Ma, using sedimentologic tools to interpret the siliciclastic fraction and ascertain whether and which portion is due to ice-related input. Previous research estimates the onset to begin at 2.75 Ma by using IRD occurrence and a sharp decline in opal accumulation (Haug et al., 2005). A reevaluation of this critical period will be important for gaining a better understanding of the onset of NHG. In this study, over 200 samples from 1.9-4.2 Ma were used to study the onset of NHG. The $>250 \mu \mathrm{m}$ siliciclastic mass accumulation rates (MAR) for the samples indicate an initial increase in abundance between 3.3 and 3.6 Ma before decreasing between 2.7 and 3.2 Ma. Another increase in abundance was observed between $2.7 \mathrm{Ma}$ and the end of the record at 1.9 Ma. The provenance, composition, and surface texture features of quartz were also analyzed. It is uncertain whether the first occurrence of $>250 \mu \mathrm{m}$ siliciclastics was the result of icerelated processes or from other mechanisms like local re-sedimentation from Bowers Ridge. The implications of both possibilities were evaluated. 


\section{ACKNOWLEDGEMENTS}

I would like to thank my advisor, Dr. Ivano Aiello. He provided me with invaluable advice and support during the course of this work. I learned a great deal during my time at Moss Landing Marine Laboratories and I am appreciative of the opportunity to work with him.

Similarly, I am grateful to Dr. Kenneth Coale and Dr. Ana Christina Ravelo for their immeasurable knowledge and guidance. They helped make my research better.

Most importantly, I am indebted to my family. Their constant encouragement and love provide the necessary support for me to pursue my goals. I could not have done this without them. They were never fazed by my bombardment of "This is the last time," "I mean this is the last time," "I promise this is the last time," "Ok this is actually the last time..." emails asking for proofreading help and sanity checks. I have the best siblings: Maria, Melissa, Buck, and Margaret who set the bar so high I should have considered pole-vaulting in high school instead of long distance running. I am especially grateful to my parents, Lisa and Buck. I am truly fortunate to be their daughter. Everything I do is made possible by their love, support, and example. This thesis is dedicated to them, and to my grandfather, Albert F. Tanner. Thank you. 


\section{TABLE OF CONTENTS}

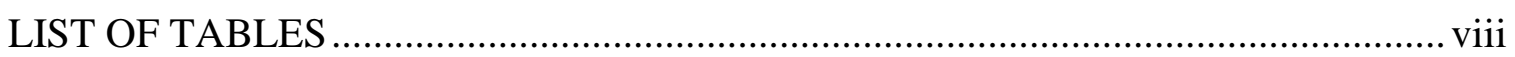

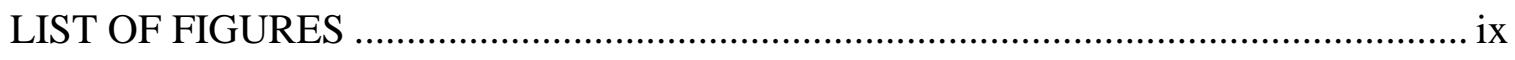

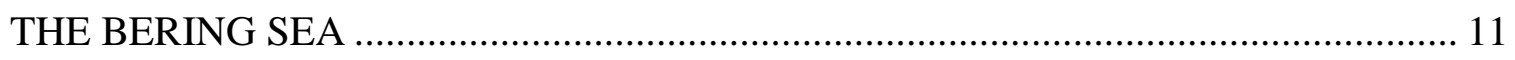

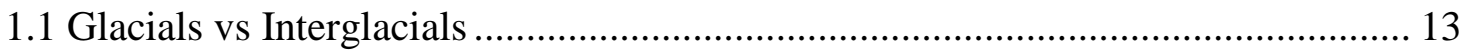

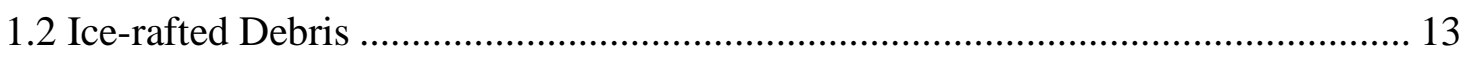

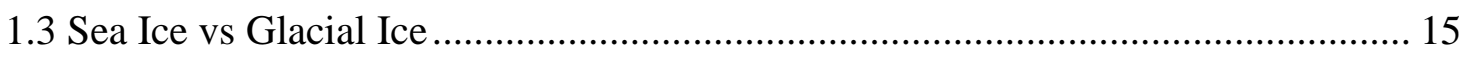

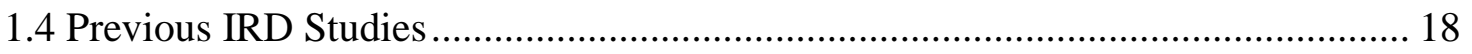

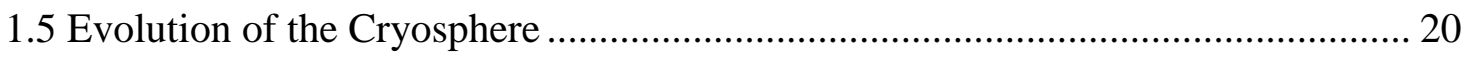

1.6 North Hemisphere Glaciation ............................................................................... 21

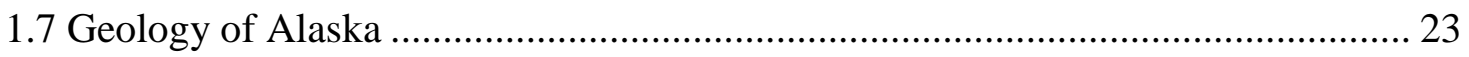

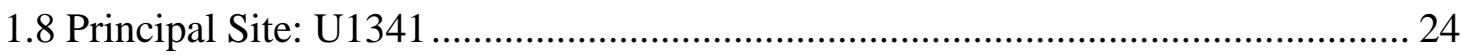

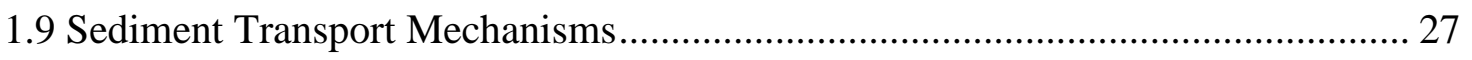

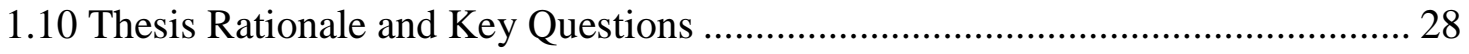

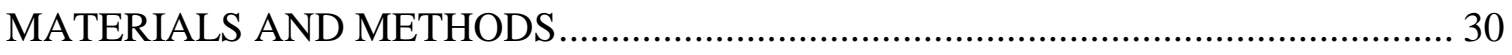

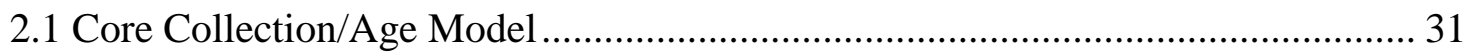

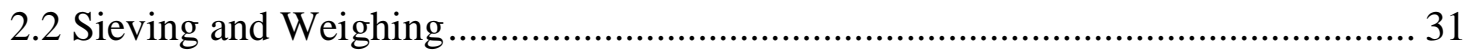

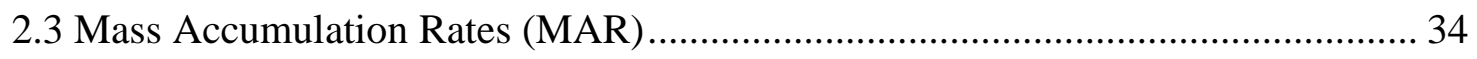

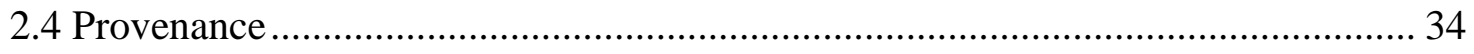

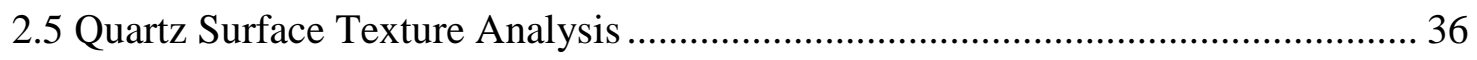




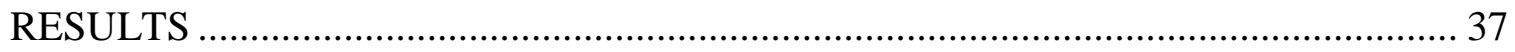

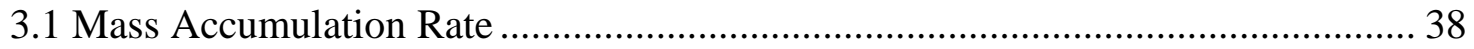

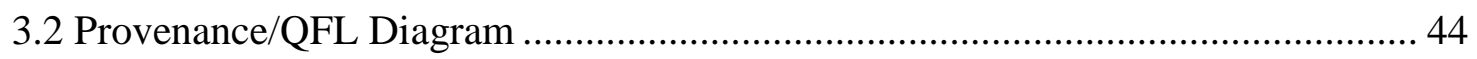

3.3 Quartz Surface Texture Analysis .................................................................. 46

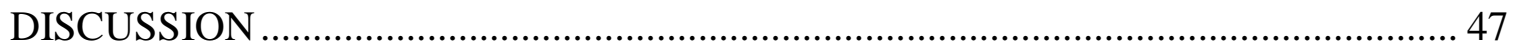

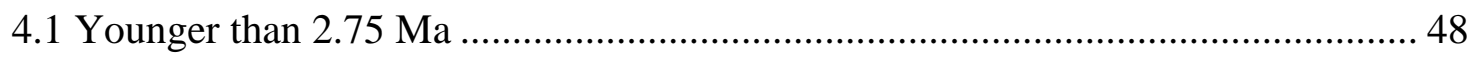

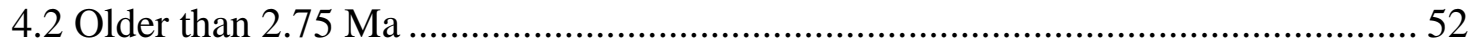

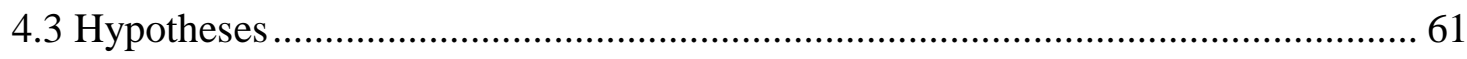

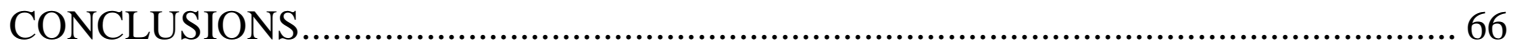

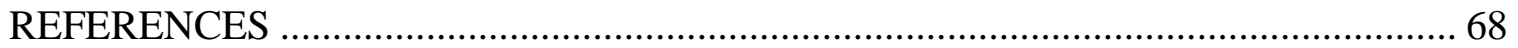




\section{LIST OF TABLES}

Table 1 Transportation by Ice.................................................

Table 2 Past Research...................................................... 20

Table 3 Age Between Samples.................................................. 31

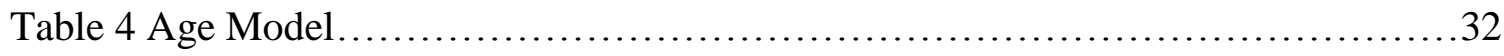

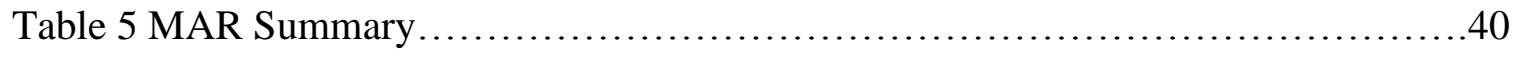

Table 6 Molén's Method.......................................................47

Table 7 Average MAR Values..............................................52 


\section{LIST OF FIGURES}

Figure 1 Transportation Mechanisms. ………………............................................. 14

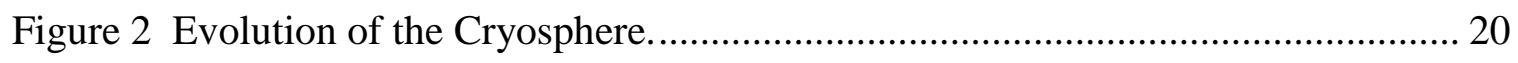

Figure 3 Onset of NHG (LR04), ...................................................................... 22

Figure 4 Geology of Alaska.................................................................................... 24

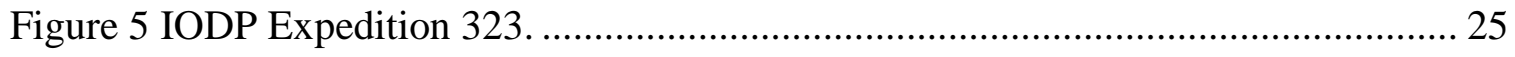

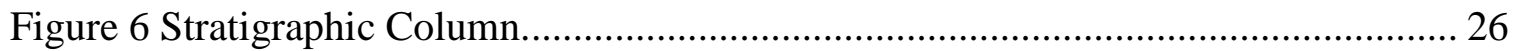

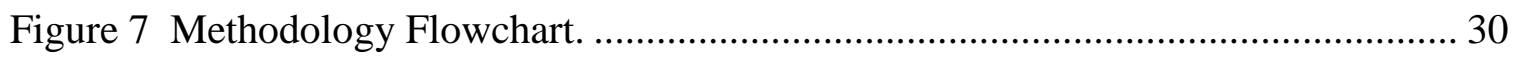

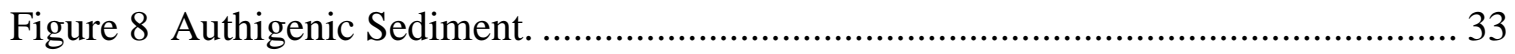

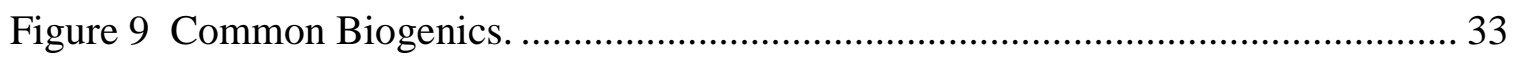

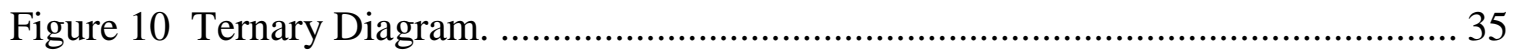

Figure $11250 \mu \mathrm{m}$ siliciclastic MAR............................................................................ 39

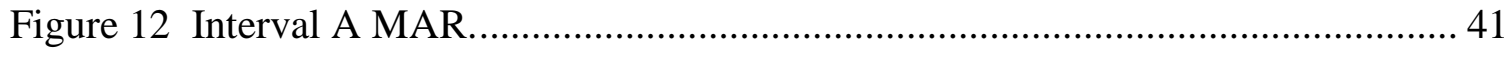

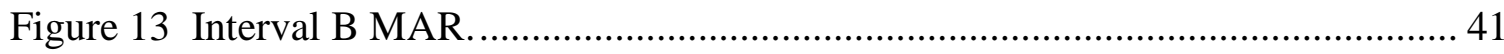

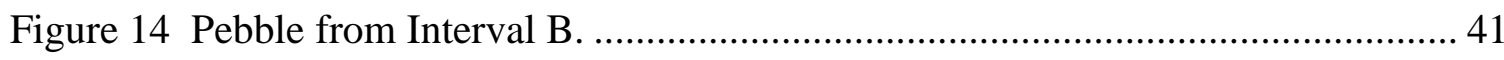

Figure 15 Interval C MAR................................................................................. 42

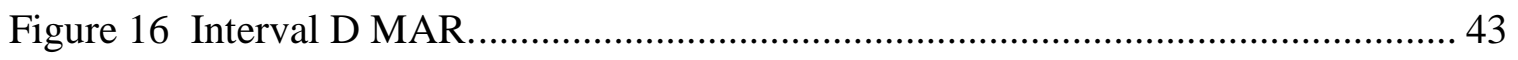

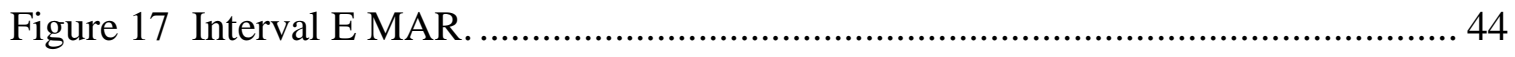

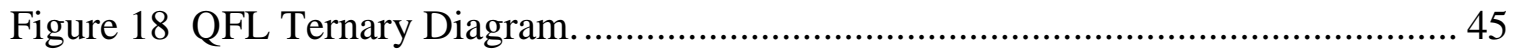

Figure 19 Common Surface Texture Features............................................................... 46

Figure 20 MAR vs Time Plot.................................................................................. 48

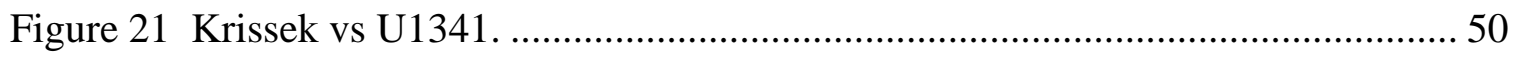




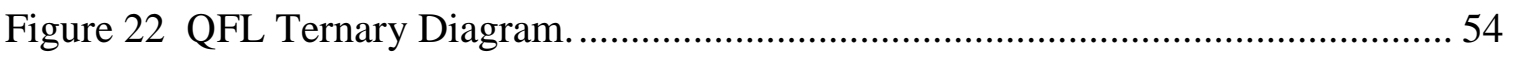

Figure 23 MGV Ternary Diagram............................................................................ 55

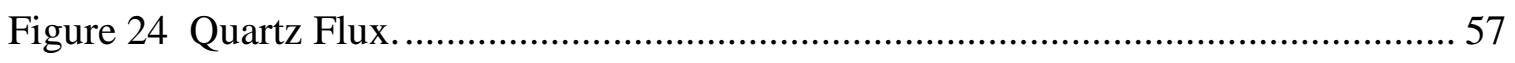

Figure 25 Suface Texture Analysis...................................................................... 59

Figure 26 Surface Texture Features Younger................................................................... 60

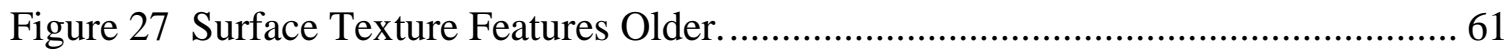

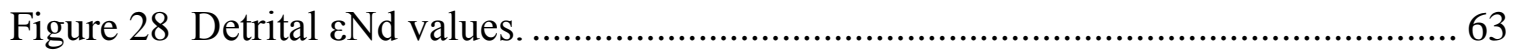

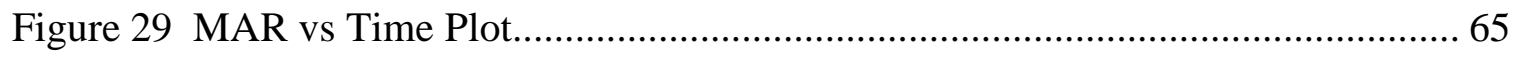




\section{The Bering Sea}

An important opportunity to study the paleoclimate and evolution of the cryosphere in the Northern Hemisphere came in 2009 with International Ocean Discovery Program (IODP)'s Expedition 323 to the Bering Sea. The long intact sediment cores that were recovered from different parts of this marginal basin contain a 5 million year (my) record of the oceanographic and climatic conditions of the region, including such major events as onset of North Hemisphere Glaciation (NHG), the mid-Pleistocene transition (MPT), and glacial-interglacial cycles. According to this record, the Northern Hemisphere experienced a significant change in climate at the end of the Pliocene with the onset of NHG. Ice sheets began to form, expand, and persist, sea surface temperatures decreased, the thermohaline circulation weakened, the concentration of atmospheric carbon dioxide decreased, sea level lowered, and the ocean became more stratified (Ravelo et al., 2004). The cause for these changes remains under debate. The shift in global climate variability that occurred during MPT, 1.2 to 0.7 million years from the 40 thousand year (ky) cycles that dominated the Pliocene and early Pleistocene to a $100 \mathrm{ky}$ cycle, can still not be fully explained (Hönish et al., 2009) and alternative hypotheses concerning the causes of this shift have been formulated (Clark et al., 2006; Raymo and Huybers, 2008). During this time, the Northern Hemisphere experienced major climatic events in the last 5 my. Evidence of those events is preserved in the sediment record in the marine cores recovered by IODP Exp 323. Understanding the mechanisms and the dynamics responsible for significant variations in climate, both regionally and globally, is 
becoming increasingly relevant in light of current projections for present and future climate change. Research into past changes in climate and ocean conditions is critical in further elucidating that system.

The geography of the Bering Sea and the surrounding land mass play an important role in both atmospheric circulation, biological productivity, and ocean circulation. The capacity of marginal seas in sub-polar regions, like the Bering Sea, to absorb atmospheric carbon dioxide allows these areas to have a substantial impact on the global carbon cycle, and therefore, on changes in global climate as well (Takahashi, 1998). The Bering Sea also influences regional climate through sea ice, which affects climate through albedo, stratification, and evaporation, and is a critical control in biological productivity and ice-related blooms (Smith et al., 2003; Katsuki and Takahashi, 2005; Caissie et al., 2010). A shallow (0-200 m) neritic area takes up about one half of the Bering Sea and today is seasonally covered by sea ice. In the deeper Aleutian Basin, however, sea ice is absent (Hood, 1983; Niebauer et al., 1999; Takahashi, 2005). Along the continental shelf is a highly productive region, in which Springer et al. (1996) estimate primary production to be 175 to $275 \mathrm{~g} \mathrm{C} / \mathrm{m}$ yr or $260 \%$ higher than the other areas in the ocean. The Bering Sea is connected to the North Pacific by the Kamchatka Strait and to the Arctic Sea through the Bering Strait, and subsequently to the, North Atlantic and is critical in ocean circulation (Takahashi, 1998; Takahashi, 2005). The exchange of surface water between the Bering Sea and the North Pacific through the Aleutian Islands is considerable and allows the Bering Sea to play a role in the conditions of the North Pacific (Aiello and Ravelo, 2012). The Bering Sea also affects the strength 
of North Pacific Intermediate Water (NPIW), which forms in the Okhotsk Sea, by varying intermediate water ventilation that occurs during glacials and interglacials (Kim et al., 2011). Thus, the Bering Sea, and the sediments that it bears, is an important region for studying major changes in climate and oceanographic conditions.

\subsection{Glacials vs Interglacials}

There are significant differences in surface water circulation, sea level, extent of sea ice, and sedimentation of the Bering Sea between glacial periods and interglacials. During glacials, sea ice formation is more extensive and nearly perennial, which results in a drop in sea level and the closure of Unimak Pass and the Bering Strait (Katsuki and Takahashi, 2005). This diminishes both the inflow of North Pacific water into the Bering Sea and Bering Sea water into the Arctic. Biogenic sedimentation is also lower during glacials than interglacials, and the source of terrigenous sediment changes. During glacials, older rocks ranging from $40-80 \mathrm{Ma}$ (based on ${ }^{40} \mathrm{Ar}-{ }^{39} \mathrm{Ar}$ data) from the Yukon River basin and northeast Russia are the dominant source of sediment (VanLaningham et al., 2009). The Bering Sea is a significant source of sediment to the Meiji Drift during glacials, whereas during interglacials, the younger (2-15 Ma based on Nd isotopic data from VanLaningham et al., 2009) Kamchatkan and Aleutian arcs are the source of sediment to the Meiji Drift just south of the Bering Sea (VanLaningham et al., 2009).

\subsection{Ice-rafted Debris}

Paleoenvironmental proxies are important tools used in reconstructing Earth's climate history. Deep-sea sediment cores, which provide the longest and most continuous 
record of paleoclimatic conditions and changes available on Earth, can go back as far as 150-170 My (Boyle, 2008). Ice-rafted debris (IRD) has widely been used as a direct indicator of glaciation. IRD are the detrital materials in marine sediments from ocean basins. Among these are the siliciclastics greater than $250 \mu \mathrm{m}$ (von Huene et al., 1973; von Huene et al., 1976; Krissek, 1995; St. John and Krissek, 1999). Icebergs and sea ice are considered the likely transport mechanisms of sediment this size since these larger particles settle out relatively rapidly during fluid flow (Tripati et al., 2008; Ruddiman, 1977). Deposited far from a continental shelf, these larger, coarser terrigenous grains are an anomaly among the finer grained pelagic or hemipelagic sediment matrix (Krissek, 1995). While pyroclastics and authigenics can be ice-rafted, there are other more likely transportation mechanisms and no clear way of identifying which portion if any has been ice-rafted (Figure 1). Therefore, to be conservative, only the siliciclastic component is considered IRD.

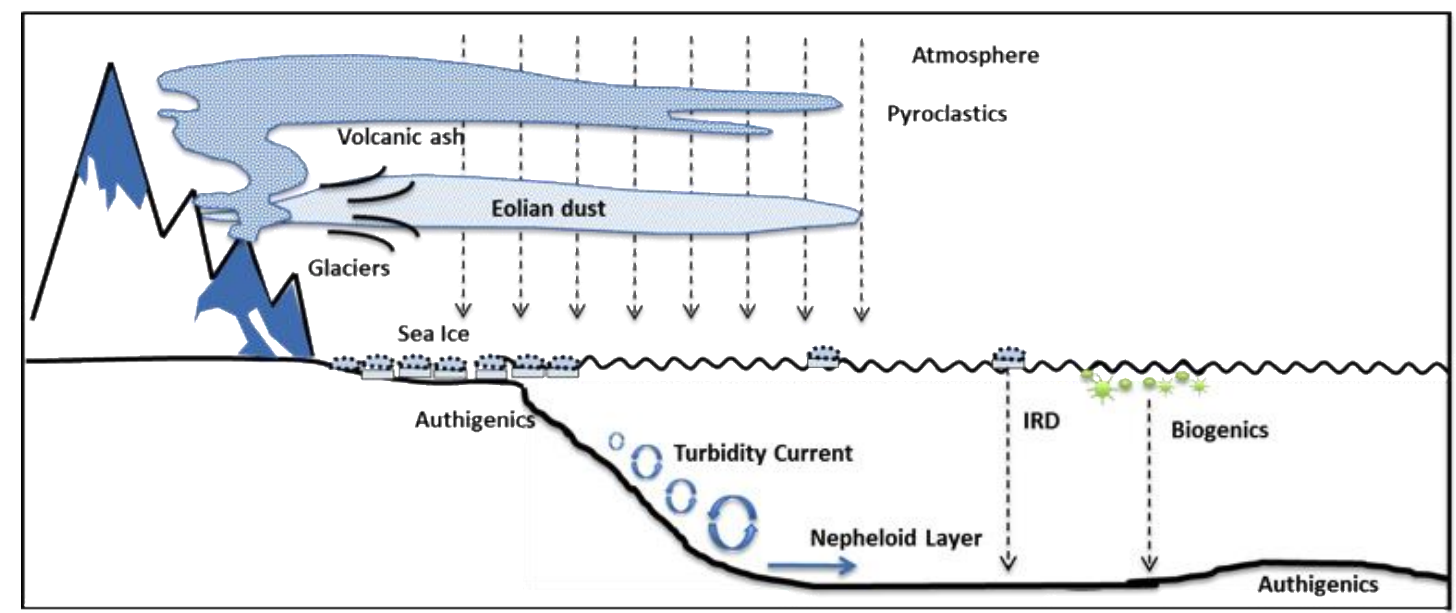

Figure 1. Transportation Mechanisms. This figure shows the different transport mechanisms of sediment to the deep sea (Modified from Lisitsyn, 2002). 
The placement of IRD gives two important pieces of information. First, the composition and geographic locations of IRD can show the glaciated source areas (see Table 8). Second, analysis of the stratigraphic distribution of IRD can reveal when continental glaciers reached sea level (Krissek, 1995). Since other possible transportation mechanisms could have been responsible for grain deposition to the deep sea, such as nepheloid layers, turbidites, and local re-sedimentation, other considerations are needed to determine if the sediment has been ice-rafted. These considerations include surface microtextures of quartz grains, provenance, and degree of sorting. To better understand the temporal and spatial onset of the NHG, IRD was used in this study as a proxy for past continental glaciation.

\subsection{Sea Ice vs Glacial Ice}

Although ice sheets are the largest and most influential factor of the Earth's climate systems (Boulton, 2006), glaciers, ice caps, and ice shelves are forceful parts of the climate as well. Ice caps are smaller than ice sheets and tend to be dome-shaped ice and snow that completely covers a mountainous area, preventing peaks or Nunataks from being visible (Molina, 2004). In contrast glaciers are classified by their size, location, and thermal regime. As glaciers and ice sheets shear the rock bed below, sediment becomes incorporated into the basal ice through abrasion, plucking, and erosion by subglacial meltwater (Glazovskii, 1989; Boulton, 2006). This sediment is delivered to the seafloor by icebergs and can be a significant input of sediment. A range of fine (silts and clays) and coarse (boulders, pebbles) granulometric fractions distinguishes deposits from iceberg rafted sediment. Therefore the sediment is less sorted and tends to be more 
rounded (Lisitzin, 2002). The sediment in sea ice comes from suspension freezing of particles in the water column or on the sediment bed, which is known as sediment entrainment. Sediment entrainment is caused by subfreezing temperatures, strong winds, and powerful turbulence in shallow, open water (Reimnitz et al., 1998). Anchor ice forms by freezing on the seafloor, capturing sediment, which later floats to the surface. The entrained sediment needs to be coarse enough to resist the drag and buoyancy of ice buildup (Arden and Wigle, 1972; Reimnitz et al., 1987). Consequently, the sediment entrained in anchor ice is typically sand and pebbles, and is less sorted than other types of sea ice, like frazil ice. When water crystallizes with suspended sediment at its center, frazil ice is formed (Lisitzin, 2002). Frazil ice commonly forms on the surface of the water where temperatures are coldest. This is commonly an unconsolidated mix of ice crystals and supercooled water. It commonly precedes the formation of pancake ice, which rafts together to form sea ice. Frazil ice preferentially entrains finer and bettersorted sediment (Reimnitz et al., 1987, Aiello and Ravelo, 2012). Melting also causes sorting, as the sediment dispersed throughout the ice is concentrated at the surface of the sea ice. As the ice begins to melt, fine sediment is carried into the sea by the meltwater, while the coarse grains remain (Reimnitz et al., 1998; Aiello and Ravelo, 2012). Overall, sediment entrained in sea ice through suspension freezing generally tends to be finer than iceberg-rafted sediment (Nürnberg et al., 1994). The sediment size of the siliciclastic fraction provides clues to determining the transport mechanism for sea ice (Table 1). 
Table 1

Transportation by Ice

\begin{tabular}{|c|c|c|c|c|c|}
\hline Туре & Mode & $\begin{array}{c}\text { Sediment } \\
\text { Description }\end{array}$ & Source & Texture & References \\
\hline \multirow{2}{*}{ Sea Ice } & Frazil & $\begin{array}{l}\text { Predominantly } \\
\text { clay and silt, } \\
\text { sorted }\end{array}$ & $\begin{array}{l}\text { Water } \\
\text { Column }\end{array}$ & $\begin{array}{l}\text { Rounded, sub- } \\
\text { rounded }\end{array}$ & $\begin{array}{l}\text { Reimnitz et } \\
\text { al., (1987); } \\
\text { Lisitzin, } \\
2002\end{array}$ \\
\hline & Anchor & $\begin{array}{c}\text { Coarse, less well } \\
\text { sorted }\end{array}$ & Seafloor & $\begin{array}{l}\text { Rounded, sub- } \\
\text { rounded }\end{array}$ & $\begin{array}{l}\text { Reimnitz et } \\
\text { al., (1987); } \\
\text { Lisitzin, } \\
2002\end{array}$ \\
\hline Glaciers & $\begin{array}{l}\text { Fracturing, } \\
\text { Abrasion, } \\
\text { Erosion }\end{array}$ & $\begin{array}{l}\text { Large range of } \\
\text { size fractions, } \\
\text { less well sorted }\end{array}$ & $\begin{array}{l}\text { One or } \\
\text { few point } \\
\text { sources }\end{array}$ & $\begin{array}{l}\text { Angular, } \\
\text { rough, uneven } \\
\text { with scores, } \\
\text { grooves and } \\
\text { striations }\end{array}$ & $\begin{array}{l}\text { Lisitzin, } \\
2002\end{array}$ \\
\hline Ice Sheets & $\begin{array}{l}\text { Fracturing, } \\
\text { Abrasion, } \\
\text { Erosion }\end{array}$ & $\begin{array}{l}\text { Large range of } \\
\text { size fractions, } \\
\text { less well sorted }\end{array}$ & $\begin{array}{l}\text { Multiple } \\
\text { point } \\
\text { sources }\end{array}$ & $\begin{array}{l}\text { Angular, } \\
\text { rough, uneven } \\
\text { with scores, } \\
\text { grooves and } \\
\text { striations }\end{array}$ & $\begin{array}{l}\text { Lisitzin, } \\
2002\end{array}$ \\
\hline
\end{tabular}




\subsection{Previous IRD Studies}

The Atlantic has been an area of interest for paleoclimate research. The Spectral Mapping (SPECMAP) project in the 1980s created a timescale going back to the early Pleistocene based on oxygen isotopes from planktonic foraminfera (Imbrie et al., 1984; Gornitz, 2009). Other important studies in the North Atlantic and Greenland Sea were done on Ocean Drilling Program (ODP) Legs 108, 151, and 172. While there have been many studies looking at IRD in the Atlantic (Shackleton et al., 1984; Andrews, 1999; Caissie et al., 2010), there has been relatively little research in the North Pacific and even less in the Bering Sea. Among the first to obtain sediment cores from the Bering Sea were Creager and Scholl (1973) on Deep Sea Drilling Project (DSDP) Leg 19. Leg 19 recovered cores from the North Pacific near the Aleutian Islands in 1992 (Rea et al., 1993; März et al., 2013). Previous IRD studies in the North Pacific have found limited IRD prior to $2.6 \mathrm{Ma}$, but IRD significantly increasing at around 2.6 Ma and 1.0 Ma (Krissek, 1995, Table 2). This finding suggests that the onset of NHG (occurring on a continent scale) at $2.6 \mathrm{Ma}$, and the intensification of NHG climate fluctuations at around 1.0 Ma (Stewart et al., 1979; Fullam et al., 1973; Conolly and Ewing, 1970; Kent et al., 1971; Rea and Schrader, 1985; Krissek et al., 1989; Krissek, 1995). Due to outdated drilling technology and poor recovery, however, it was not until IODP Expedition 323 in 2009 that long intact sediment cores from the Bering Sea were recovered and with it a 5 my climatic and oceanographic record of the North Hemisphere (Cook et al., 2005; Okazaki et al., 2005; Takahashi et al, 2005; IODP Exp 323 Scientists, 2010). 
Table 2

Past Research

\begin{tabular}{|c|c|c|}
\hline Previous Work & Location & Key Findings \\
\hline Kent et al., 1971 & North Pacific & $\begin{array}{l}\text { Found IRD at } 2.6 \mathrm{Ma} \text { with increase of } \\
\text { ice-rafting beginning at } \sim 1.2 \mathrm{Ma}\end{array}$ \\
\hline $\begin{array}{l}\text { von Huene et al., } \\
1973\end{array}$ & $\begin{array}{l}\text { Gulf of Alaska, } \\
\text { DSDP Leg } 18\end{array}$ & $\begin{array}{l}\text { Demonstrated that the abundance of the } \\
\text { coarse-sand fraction ( } 250 \mu \mathrm{m} \text { to } 2 \mathrm{~mm}) \text { is } \\
\text { a valid indicator of IRD abundances }\end{array}$ \\
\hline $\begin{array}{l}\text { Rea and Schrader, } \\
1985\end{array}$ & $\begin{array}{l}\text { North Pacific, } \\
\text { Bering Sea, DSDP } \\
\quad \text { Legs } 18,19\end{array}$ & Onset of IRD at $2.6 \mathrm{Ma}$ \\
\hline Krissek et al., 1985 & $\begin{array}{l}\text { NW Pacific, ODP } \\
\text { Leg } 145\end{array}$ & $\begin{array}{c}\text { Found IRD at } 2.6 \mathrm{Ma} \text { with an increase } \\
\text { beginning at } 1.0 \mathrm{Ma}\end{array}$ \\
\hline Krissek, 1996 & $\begin{array}{c}\text { NW \& NE } \\
\text { Pacific, ODP Leg } \\
145\end{array}$ & $\begin{array}{l}\text { IRD occurrence consistent with Kent et } \\
\text { al., } 1971\end{array}$ \\
\hline $\begin{array}{l}\text { McKelvey et al., } \\
1995\end{array}$ & $\begin{array}{c}\text { NW \& NE } \\
\text { Pacific, ODP Leg } \\
145\end{array}$ & $\begin{array}{l}\text { NW Pacific IRD derived from the } \\
\text { western Bering Sea and the Kamchatka } \\
\text { Peninsula, NE Pacific IRD derived from } \\
\text { SE Alaska }\end{array}$ \\
\hline $\begin{array}{l}\text { Prueher and Rea, } \\
1998\end{array}$ & $\begin{array}{c}\text { NW \& NE } \\
\text { Pacific, ODP Leg } \\
145\end{array}$ & $\begin{array}{l}\text { Sudden and drastic input of IRD a } 2.67 \\
\text { Ma in the North Pacific. Propose } \\
\text { intensification could be linked to } \\
\text { increased volcanism }\end{array}$ \\
\hline $\begin{array}{l}\text { St. John and } \\
\text { Krissek, } 1999\end{array}$ & $\begin{array}{l}\text { North Pacific, } \\
\text { DSDP } 580\end{array}$ & $\begin{array}{l}\text { Found regional spatial and temporal } \\
\text { differences in IRD in the North Pacific }\end{array}$ \\
\hline März et al., 2013 & $\begin{array}{l}\text { Bering Sea, IODP } \\
\quad \text { Exp } 323\end{array}$ & $\begin{array}{c}\mathrm{SiO}_{2 X s} \text { accumulation rates suggest NHG } \\
\text { onset at } 2.6 \mathrm{Ma}\end{array}$ \\
\hline
\end{tabular}




\subsection{Evolution of the Cryosphere}

The sedimentary record has revealed that Earth's climate over the last 65 million years has ranged from warm periods with ice-free poles to cold periods with expansive continental ice sheets (Zachos et al., 2001). These changes in climate are largely reflections in the changes of Earth's orbital parameters: eccentricity, obliquity, and precession, and plate tectonics (Zachos et al., 2001). Using delta oxygen-18 isotopes $\left(\delta^{18} \mathrm{O}\right)$ from benthic foraminifera collected from marine sediment cores globally distributed, several researchers have been able to establish a record of paleoclimate and polar ice volume, as can be seen in Figure 2 (Zachos et al., 2001; Lisiecki and Raymo, 2005).

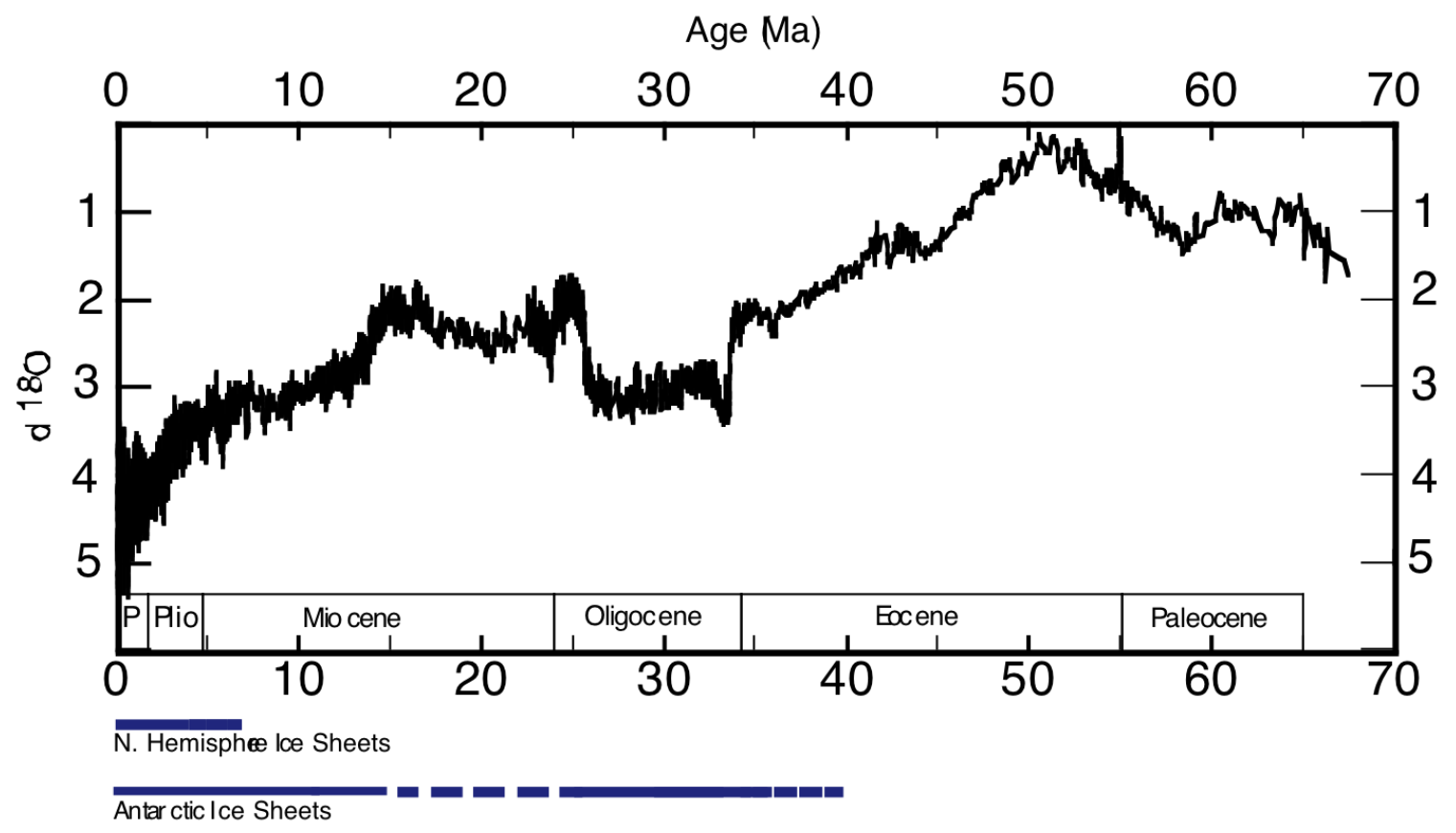

Figure 2. Evolution of the Cryosphere. Ice sheets began forming in Antarctica in the late Eocene whereas glaciation began in the northern hemisphere around the Pliocene (Adapted from Zachos et al., 2001 and Lisiecki and Raymo, 2005). 
These records show that ice sheets began to develop in Antarctica nearly 40 million years ago and near the end of the Pliocene in the North Hemisphere. The onset and development of Antarctic glaciation during the early Eocene is widely agreed upon (Zachos et al., 2001; DeConto and Pollard, 2003; Coxall et al., 2005); however, the beginning of glaciation in the North Hemisphere remains under debate (Tripati et al., 2005). Eldrett et al (2007) point to problems in preservation of the sedimentary record through the early Cenozoic in cores from the North Hemisphere that could have been caused by stronger ocean circulation and/or a drop in sea level due to Antarctic ice sheets (Eldrett et al., 2007). Due to the poor records that have been recovered so far, they argue that the lack of ice-rafted debris (IRD) found in sediments that date back to before the mid-Miocene cannot rule out an earlier onset of glaciation in the North Hemisphere.

\subsection{North Hemisphere Glaciation}

The North Hemisphere experienced a significant change in climate at the end of the Pliocene (Figure 3). Ice sheets began to form, expand, and persist. Sea surface temperatures cooled, the thermohaline circulation weakened, the concentration of atmospheric carbon dioxide decreased, sea level lowered, and the ocean became more stratified (Ravelo et al., 2004). 


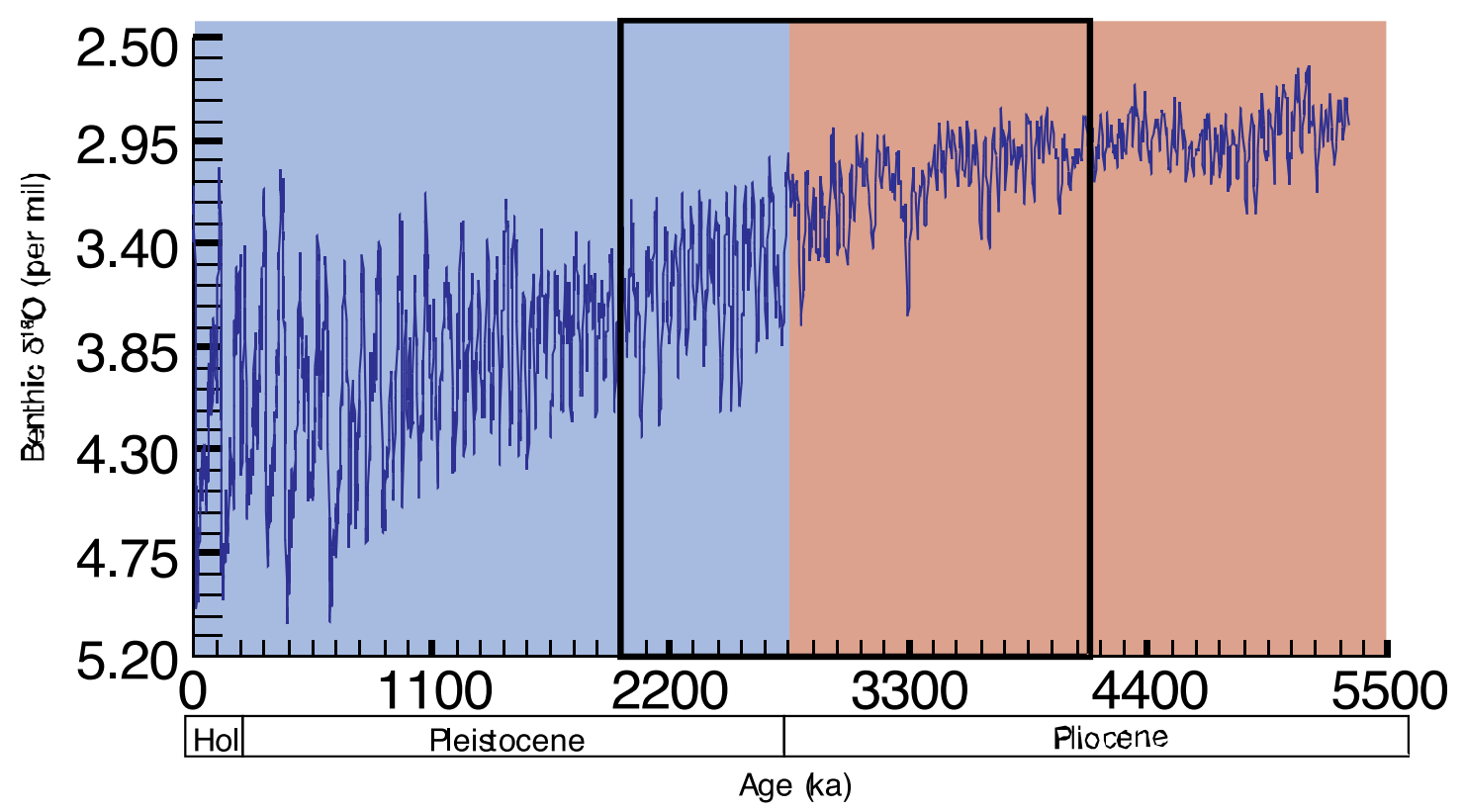

Figure 3. Onset of NHG (LR04). The gradual cooling that began at the beginning of the Pliocene intensified with onset of North Hemisphere Glaciation. The late Pliocene was characterized by warmer SSTs (red) than the Pleistocene (blue). The area in outlined in the black box is the time period covered by this study (Adapted from Lisiecki and Raymo 2005).

The cause for these changes is still under debate. According to the Milankovitch theory, glaciation needs cool summers in the northern latitudes to prevent melting and ablation (Maslin et al, 1998). This, along with enough moisture, allows the snowpack to persist and expand which increases surface albedo and acts as a positive feedback (Driscoll and Haug, 1998). These favorable conditions for glaciation were present at the end of the Pliocene through lower summer insolation and possibly, an enhanced thermohaline circulation that would have transported more moisture northward (Raymo et al., 1992; Driscoll and Haug, 1998). These factors, in combination with certain tectonic events, could have led to the development of North Hemisphere Glaciation (NHG) (Maslin et al., 1998). Some of the theories include an increase in volcanism (Prueher and 
Rea, 2001), the closure of the Central American seaway (Driscoll and Haug, 1998), the uplift of the Himalayas (Raymo et al, 1988), and the ending of a permanent El Nino (Molnar and Cane, 2002; Philander and Fedorov, 2003; Ravelo et al., 2004; Wara et al., 2005; Lunt et al., 2008).

\subsection{Geology of Alaska}

In determining the spatial scale of glaciation in the North Hemisphere, understanding the geology of Alaska and Kamchatka is critical. Alaska is divided into two key tectonic and geological regions: the Arctic coastal plains and the Cordillera. Within the Cordillera, there are three main subdivisions. These include a northern mountainous region, a central intermontane area, and a southern mountainous region (Plafker and Berg, 1994). The Cordillera includes the Yukon River Basin and the Anadyr River Basin. Both are dominated by sedimentary and metasedimentary geologies with some volcanic, plutonic, and metamorphic regions (Figure 5; VanLaningham et al, 2009). The geology of Kamchatka is similar, but with a few more regions dominated by volcanics than Alaska (VanLaningham et al, 2009). 


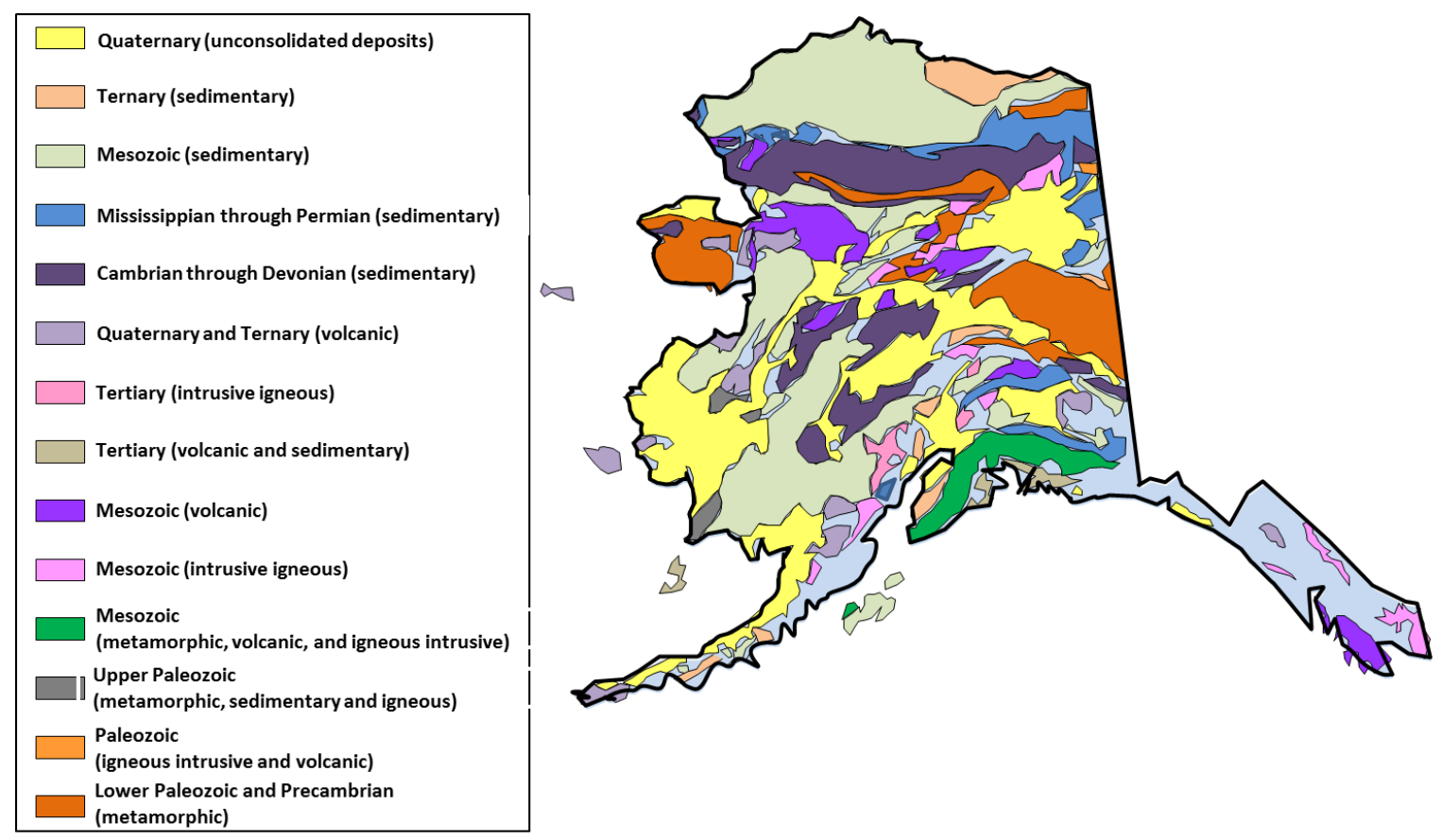

Figure 4. Geology of Alaska. Alaska is divided into two key tectonic and geological regions: the Arctic coastal plains and the Cordillera. Paleozoic and Mesozoic sedimentary rocks are the most widespread (Adapted from U.S. Geological Survey digital data).

St. John and Krissek (1999) found that the Northeast Pacific supplied more IRD than the Northwest Pacific. They also were able to determine that the presence of chert and rhodochrosite indicated the source to be Kamchatka Peninsula. Their conclusions pinpoint Southeast Alaska as the greatest source of IRD in the North Pacific possibly due to atmospheric circulation and geography that promoted more extensive glaciers.

\subsection{Principal Site: U1341}

There are two major topographic features in the Bering Sea: Shirshov Ridge, which separates the Aleutian Basin into an eastern and western part, and Bowers Ridge, which extends north from the Aleutian Island Arc (Creager and Scholl, 1973; Takahashi, 2005). Other important features include Bering Slope and Umnak Plateau. Researchers 
on the Integrated Oceanic Drilling Program (IODP) Expedition 323 were able to collect marine sediment cores from the Bering Sea at seven sites: three along the Bering Sea shelf (U1343, U1344, U1345), three along Bowers Ridge (U1340, U1341, U1342), and one on the Umnak Plateau (U1339). Previous work on past DSDP and Ocean Drilling Program (ODP) sites (Leg 145: Sites 881, 882, 883, 884) near the Bering Sea found a sharp increase in IRD at 2.6-2.75 Ma (Krissek, 1995; Maslin et al., 1996; Figure 5).

Site U1341 is located on the western side of Bowers Ridge, which is a submerged volcanic arc formed during the Tertiary age (Cooper et al, 1987; Märtz et al., 2013). It provides a 4.3 million year record of the climatic and oceanographic conditions of the Bering Sea. For this reason, and because of its distance from the shelf, it can be used to study IRD.

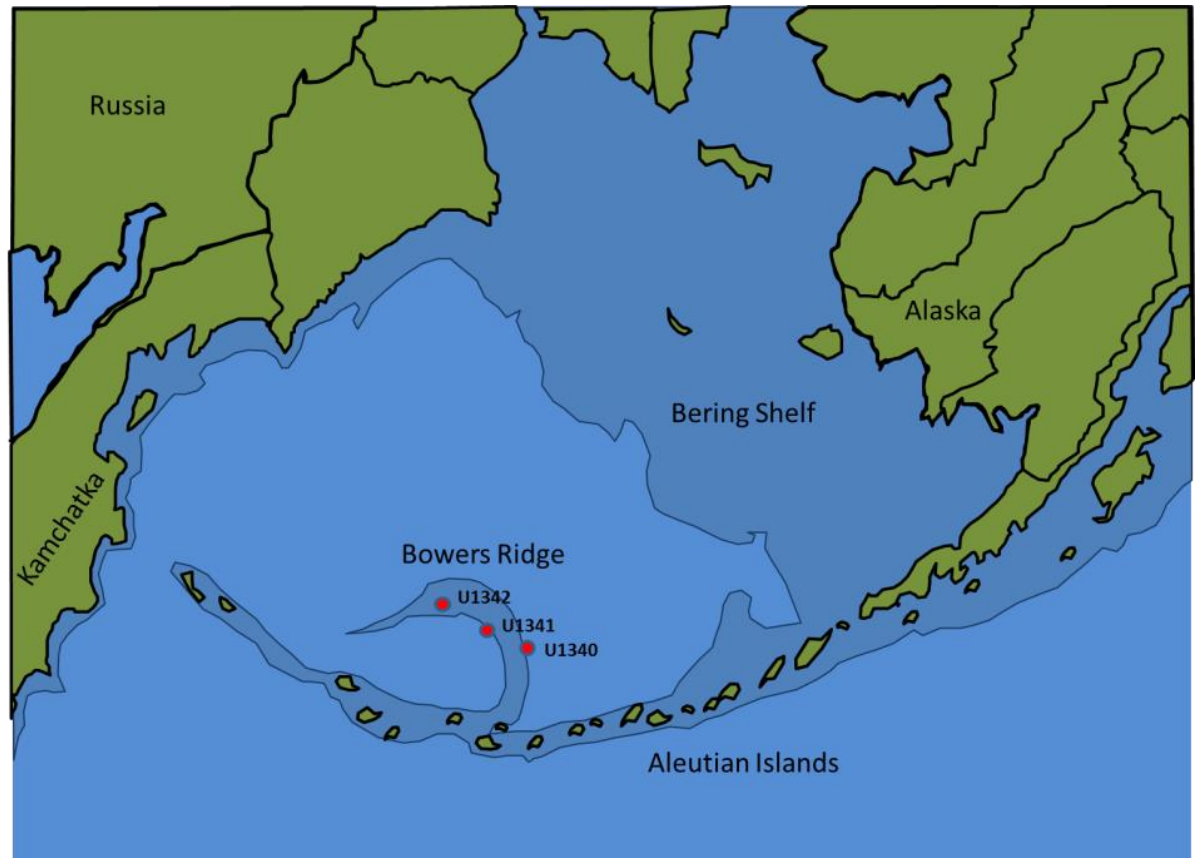

Figure 5. IODP Expedition 323. Drilling Sites on Bowers Ridge in the Bering Sea from IODP Expedition 323 in 2009 (Adapted from IODP Expedition 323 Scientists, 2010). 
Three holes were drilled at this site, with Hole U1341B being the deepest at 604.5 meters below seafloor (mbsf) (Exp 323 Scientists, 2010). The sedimentation rates at this site are approximately linear at $12 \mathrm{~cm} / \mathrm{ky}$, which is relatively high compared to other Bering Sea sites (IODP Exp 323 Scientists). The environmental conditions during sediment deposition are reflected in the distribution of the sedimentary components. The variations in lithology indicate that large-scale changes or events have occurred in the Bering Sea and are recorded in the sediment cores (Exp 323 Scientists, 2010). These events include onset of NHG. The lithology of the sediments are predominantly biogenic and siliciclastic with minor amounts of volcanic material (Figure 6).

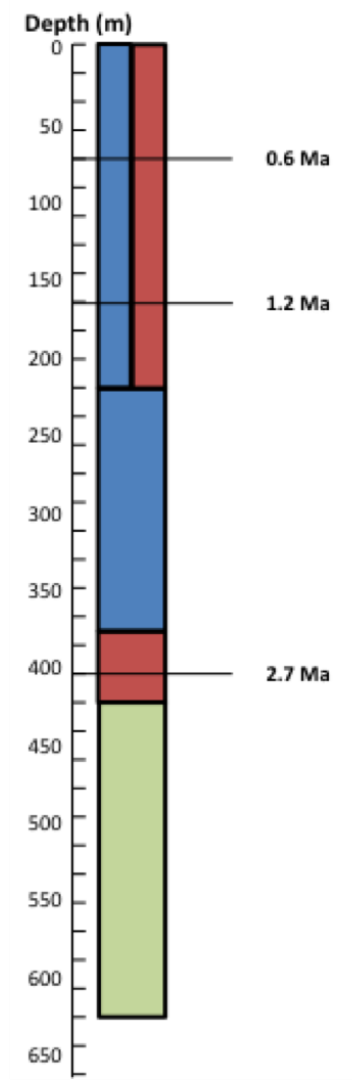

Diatom Ooze

Diatom Mud

Diatom Ooze (with sponge spicules)

Figure 6. Stratigraphic Column. The sediment at U1341B is dominated by biogenics especially diatoms (Adapted from Aiello and Ravelo, 2012). 
The biogenics are mainly composed of diatoms with some radiolarians, foraminifera, and nannofossils (Exp 323 Scientists, 2010). U1341B is divided into two lithologic units. The younger unit (Unit I) is composed of alternating subunits of diatom silt, diatom clay, and diatom ooze. At 1.6 Ma, this changes to Unit II, which is characterized by its predominance of diatom ooze (Exp 323 Scientists, 2010). This change in lithology coincides with changes in the intensity of the magnetic susceptibility record and the abundance of calcareous tests (Exp 323 Scientists, 2010). Laminated intervals occur throughout U1341B, which indicate dysoxia. Dropstones begin occurring at $\mathrm{U} 1341 \mathrm{~B}$ at roughly 2.6 Ma and increase in frequency at $1.8 \mathrm{Ma}$ (Exp 323 Scientists, 2010). Isolated dropstones were found at U1340 as early as 2.8 Ma (Exp 323 Scientists, 2010). There is also a volcaniclastic layer several meters thick that occurs around $2.7 \mathrm{Ma}$ in $\mathrm{U} 1340 \mathrm{~A}$ right above a gap in the sediment record.

\subsection{Sediment Transport Mechanisms}

Due to the open ocean setting, there are potentially fewer sediment sources capable of transferring sediment $250 \mu \mathrm{m}$ to Bowers Ridge (Figure 1). These include nepheloid layers, turbidity currents, local re-sedimentation from Bowers Ridge, sea ice, and icebergs. Bottom nepheloid layers are areas of increased turbidity as a result of thermohaline currents and internal waves (McCave, 2013). They typically consist of particles less than $2 \mu \mathrm{m}$ and occur near continental shelves (McCave 1986; McCave 2013). While they are an effective means of transporting finer grained sediment and larger aggregated particles, they lack the necessary energy to transport significant amount 
of coarse particles over long distances. Turbidity currents are capable of moving a wide range of size particles down slopes. Site U1341 is on the slope of Bowers Ridge and is in an area that could possibly be affected by turbidity currents. The $>250 \mu \mathrm{m}$ siliciclastics found at U1341 could be the result of local re-sedimentation from Bowers Ridge. If this were the case, the lithology of the $>250 \mu \mathrm{m}$ siliciclastics recovered would be similar to Bowers Ridge, which is submerged volcanic arc. According to Cooper et al (1970) and Wanke et al (2012) Bowers Ridge had subsided below sea level by the middle Miocene. Since Bowers Ridge was possibly no longer subaerial, local re-sedimentation of sediment after the middle Miocene is not likely or of minor significance. Sea ice and icebergs are effective methods of transporting sediment in a range of sizes over great distances. Sea ice would have extended over the continental shelf and possibly parts of the deeper Aleutian basin. As glaciers and ice sheets shear the rock bed below, sediment becomes incorporated into the basal ice through abrasion, plucking, and erosion by subglacial meltwater (Glazovskii, 1989; Boulton, 2006). This sediment is delivered to the seafloor by icebergs and can be a significant input of sediment. The sediment transported via ice related processes would be predominantly terrigenous, and the quartz grains would display microtextural features indicative of ice transport.

\subsection{Thesis Rationale and Key Questions}

Sediment cores are an important source of paleoclimatic data. The sediment cores act as recording devices, providing insight into the occurrence of geologic and climatic events. The causes for the observed cooling trend that began in the Eocene, the timing, 
the differences in evolution of the cryosphere between hemispheres and between oceans and whether the intensification of the NHG occurred at $2.7 \mathrm{Ma}$, remain under debate.

Using sediment core samples from Site U1341 in the Bering Sea, the chief aim of this thesis is to examine the record between approximately 1.9 and 4.2 Ma with a sample every $5 \mathrm{ky}$ to every $10 \mathrm{ky}$, using sedimentologic tools to quantify temporal variabilities at millennial scales the coarse $(>250 \mu \mathrm{m})$ fraction of the siliciclastic component. Using sedimentologic criteria based on our modern understanding of the mechanism that entrains and delivers IRD, the goal is also to ascertain whether and which portion of the siliciclastic input is due to ice-related processes. Since a number of previous research (Kent et al., 1971; Krissek, 1995; Haug et al., 2005) suggest that the onset of the NHG began $\sim 2.7$ Ma this research focused on this critical period. Over 200 samples from the time period of interest are used to study the onset of NHG. With this data, it will be possible to determine if the NHG occurred gradually or abruptly, and to develop an improved record of how the modern cryosphere evolved.

The key questions that are addressed are:

1. What is the overall trend of $>250 \mu \mathrm{m}$ siliciclastics through time for the Being Sea and how does that compare to other IRD records from the North Pacific? Is there a clear change in flux of IRD at $\sim 2.7 \mathrm{Ma}$ ?

2. What is the mechanism of delivery responsible for the deposition of $>250 \mu \mathrm{m}$ siliciclastics to Bowers Ridge?

3. Do changes in the source of IRD occur during the study period? Is there a difference in IRD concentration and composition before and after 2.7 Ma? 


\section{Materials and Methods}

A $>250 \mu \mathrm{m}$ siliciclastics record from Bowers Ridge was determined using 250 samples with a temporal resolution that ranges from one sample every $7 \mathrm{ky}$ to $28 \mathrm{ky}$ (Table 3, see age model in Table 4, Figure 7).

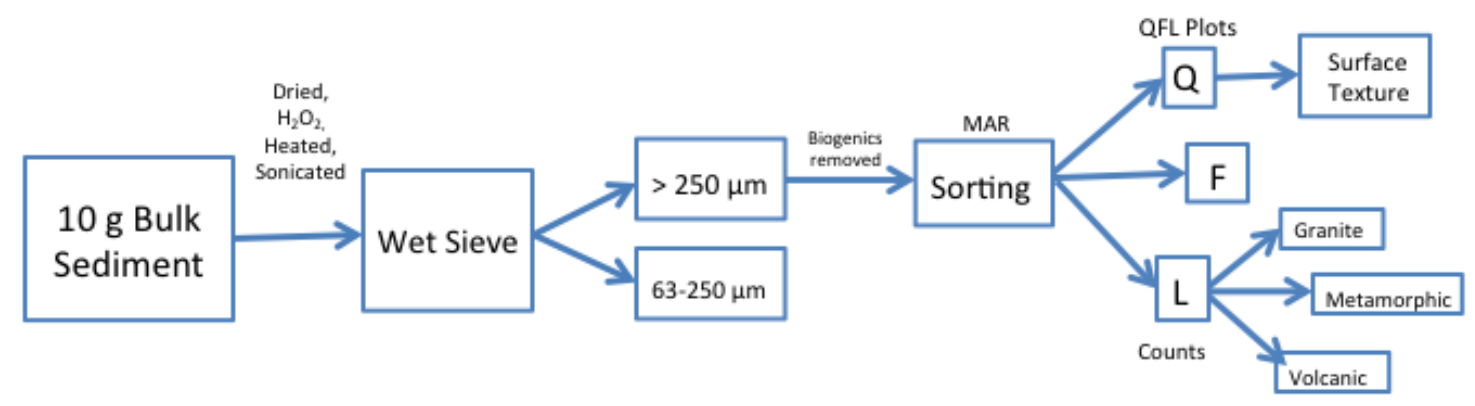

Figure 7. Methodology Flowchart. This figure summarizes the key elements in the methodology used in this project.

Table 3

Age Between Samples

\begin{tabular}{l|c|c}
\hline & Range (Age Ma) & Average (ky) \\
\hline All & $1.95-4.27$ & 10.37 \\
Interval A & $1.95-2.49$ & 28.26 \\
Interval B & $2.49-2.97$ & 9.02 \\
Interval C & $2.97-3.19$ & 9.80 \\
Interval D & $3.19-3.53$ & 7.52 \\
Interval E & $3.53-4.27$ & 8.68 \\
\hline
\end{tabular}




\subsection{Core Collection/Age Model}

The marine sediment cores used in this study were obtained from the United States Implementation Organization drill ship, JOIDES Resolution. The coring systems used on board were the Advanced Piston Coring, which can drill to a depth of $438 \mathrm{~m}$ below seafloor (DSF) and the Extended Coring Barrel that can drill to 600 m DSF (März et al., 2013; Exp 323 Scientists, 2010). A composite depth scale was made from a splice of Holes 1341A, B, and C according to their stratigraphic position (März et al., 2013; Table 4). A preliminary age model was developed shipboard and updated onshore using diatom biostratigraphy, magnetic properties, and assuming linear sedimentation rates (Expedition 323 Scientists, 2010; Takahashi et al., 2011; Teraishi et al., 2012; März et al., 2013).

Table 4

Age Model

\begin{tabular}{ccccc}
\hline $\begin{array}{c}\text { Depth } \\
\text { CSF-A } \\
(\mathrm{m})\end{array}$ & $\begin{array}{c}\text { Depth } \\
\text { CCSF-A } \\
(\mathrm{m})\end{array}$ & Control point & $\begin{array}{c}\text { Sedimentation } \\
\text { rate }(\mathrm{m} / \mathrm{myrs})\end{array}$ & $\begin{array}{c}\text { Age } \\
(\mathrm{Ma})\end{array}$ \\
\hline 0 & 0 & & 113.962 & 0 \\
32.9 & 34.2 & Depth of LO Proboscia curvirostris & 111.384 & 0.3 \\
82.5 & 87.8 & Brunehes bottom & 202.085 & 0.781 \\
137.8 & 146.6 & Jaramillo bottom & 162.015 & 1.072 \\
245.5 & 261.0 & Depth of RI N. seminae & 157.898 & 1.778 \\
367.8 & 387.7 & Gauss top & 137.900 & 2.581 \\
535.9 & 555.8 & Depth of FO N. koizumii & 137.900 & 3.8 \\
\hline
\end{tabular}

Note. Updated from Expedition 323 Scientists.

\subsection{Sieving and Weighing}

The first step in developing a mass accumulation rate is isolating the $>250 \mu \mathrm{m}$ siliciclastics and calculating its weight relative to the beginning sample weight. Roughly 
$10 \mathrm{~g}$ of each sample was measured out and placed in the oven for approximately 20 minutes or until dry. The samples were then reweighed to determine the dry weight. Next, the samples were submerged in $5 \mathrm{~mL}$ of $10 \%$ hydrogen peroxide and warm deionized water $\left(40^{\circ} \mathrm{C}\right)$. The samples then sat for 5 minutes. The hydrogen peroxide and water were carefully removed using a $0.10 \mathrm{~mL}$ pipette. Fresh deionized water and a few drops of sodium hexametaphosphate were added, and the samples were disaggregated ultrasonically for 5 minutes. Then the samples were wet sieved at $63 \mu \mathrm{m}$ and $250 \mu \mathrm{m}$, dried using heat lamps, and weighed again after cooling to room temperature. For a handful of samples, disaggregation was not completely effective and ultrasonication had to be repeated for an additional 5 minutes.

Since only the siliciclastic component of the $>250 \mu \mathrm{m}$ fraction is considered IRD, it is important to remove all other components. So, once the $>250 \mu \mathrm{m}$ size fraction was isolated, the biogenics, authigenics, and pyroclastics were removed under a dissecting microscope using 400x magnification and the samples were weighed again (Figures 8 and 9).

The weight was then normalized to the starting dry weight and is a measure of medium and coarse sand abundance. The resulting ratio of the dry weight of the medium to coarse siliciclastic fraction to the dry sample weight is the $>250 \mu \mathrm{m}$ siliciclastic weight percent (referred to as IRD Wt\% in the below equation). 


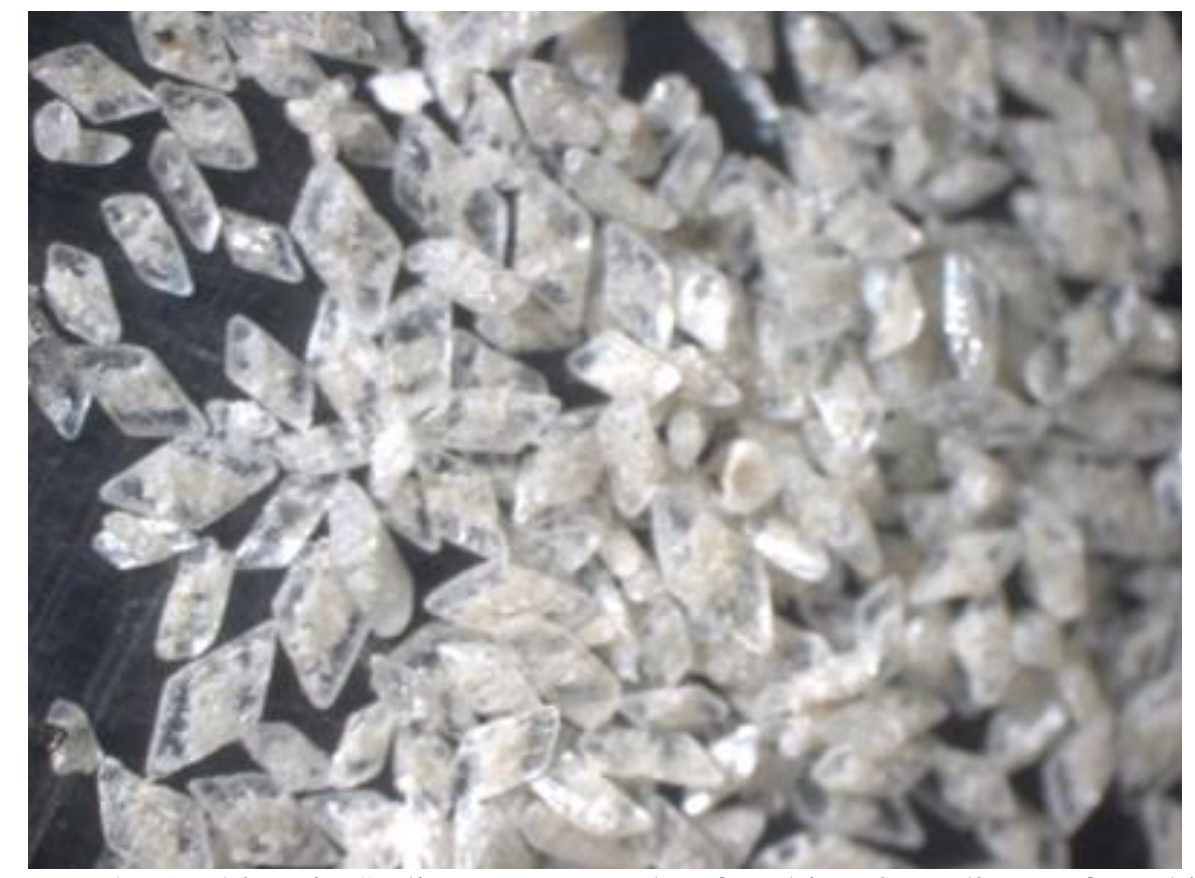

Figure 8. Authigenic Sediment. Example of authigenic sediment found in several U1341B samples (Photograph by author).

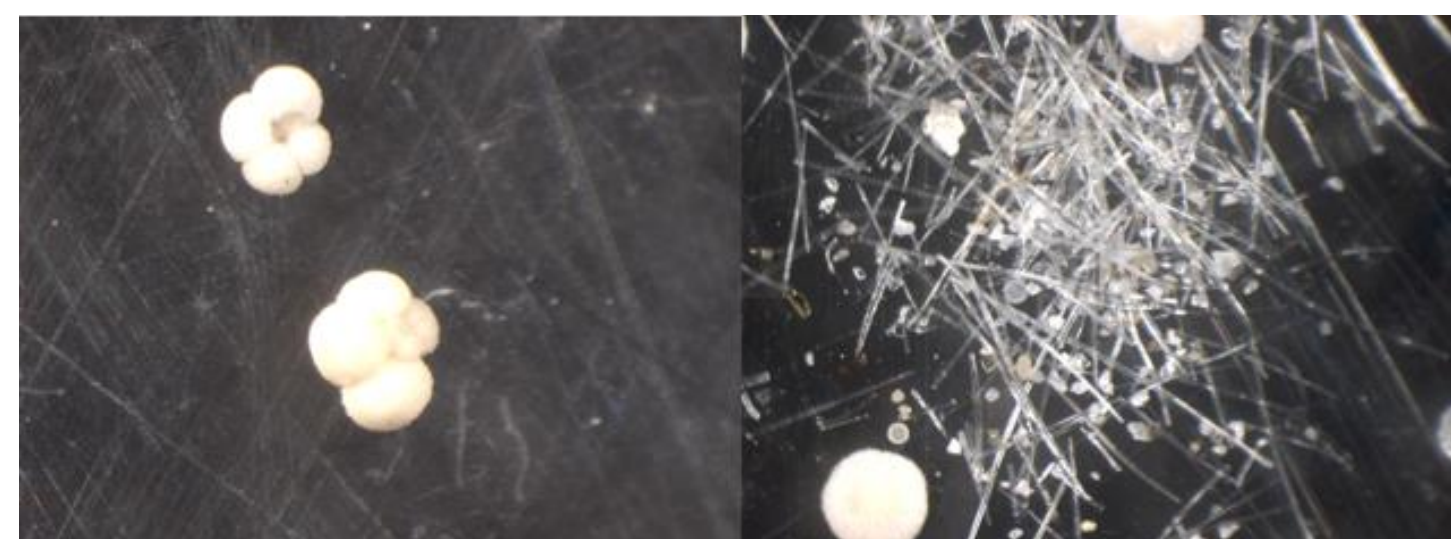

Figure 9. Common Biogenics. Forams (left), sponge spicules and radiolarians (right) were among the most common types of biogenics found in U1341B samples (Photograph by author).

The $63-250 \mu \mathrm{m}$ fraction was recovered, dried, and weighed. However, due to the relatively high abundance of grains in this fraction, the siliciclastic portion was not isolated or quantified beyond a weight percent. 


\subsection{Mass Accumulation Rates (MAR)}

Mass accumulation rates (MAR) are used to quantify the flux of a sedimentary component taking in consideration both the sedimentation rate and bulk density of the sediment. Both weight percent and MARs are calculated for each sample.

For the $>250 \mu \mathrm{m}$ siliciclastics the MAR is calculated it using the equation below:

$$
\text { IRD MAR }=\text { IRD Wt } \% \text { DBD } \times \text { LSR }
$$

Where IRD wt $\%$ is the normalized weight percent of the $>250 \mu \mathrm{m}$ siliciclastic size fraction, DBD is the dry bulk density $\left(\mathrm{g} / \mathrm{cm}^{3}\right)$, and LSR is the linear sedimentation rate $(\mathrm{cm} / \mathrm{ky})($ Krissek, 1995). The dry bulk density data and linear sedimentation rate were obtained from Exp 323 Shipboard data. DBD ranged from 1-2 $\mathrm{g} / \mathrm{cm}^{3}$ and LSR ranged from $13.79-15.23 \mathrm{~cm} / \mathrm{ky}$.

\subsection{Provenance}

The purpose of a provenance analysis is to determine the source rock of a siliciclastic sediment and based on a knowledge of the geology of the potential source areas, to reconstruct the location of the rock from which the sediment originated from. This investigation involves examining the composition and texture of the sediment (Pettijohn et al., 1987; Weltje and Eynatten, 2004). Dickinson and Suczek (1973) established a relationship between sandstone composition and plate tectonics. The three general groups that Dickinson and Suczek (1973) use in their classification are:

continental block, magmatic arc, and recycled orogeny (Figure 10). 


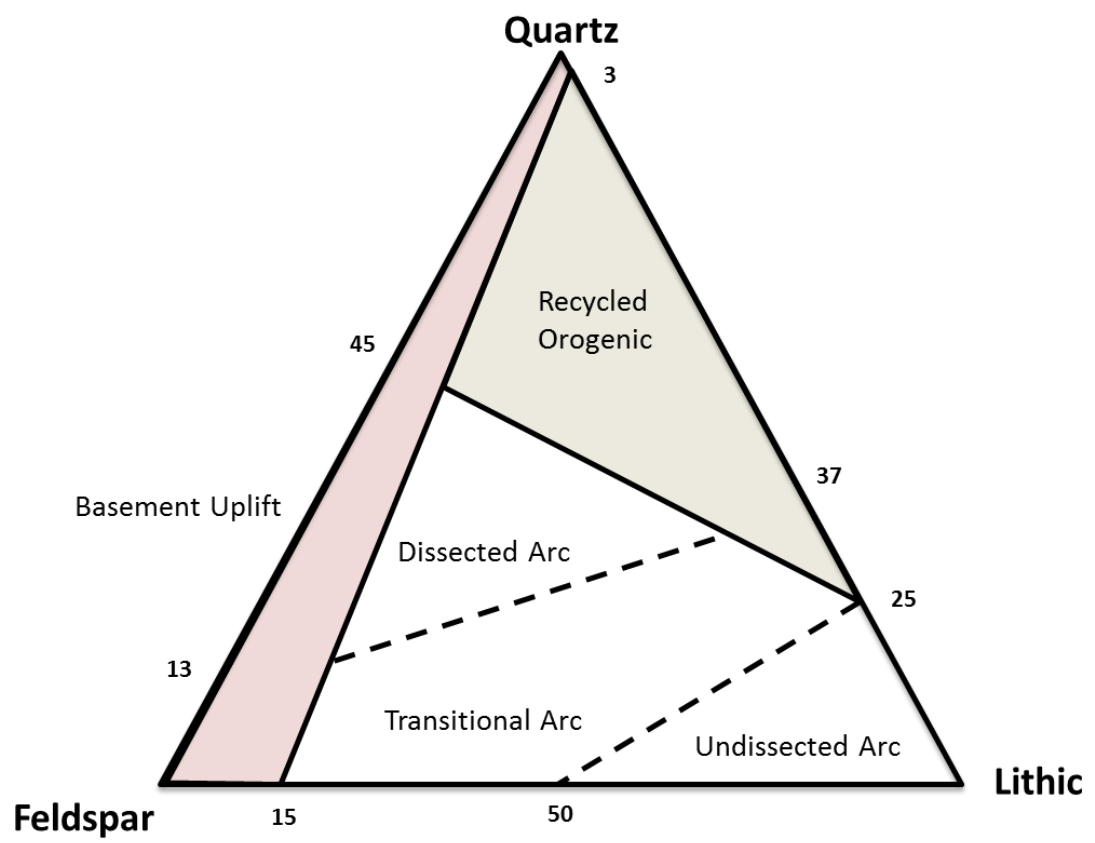

Figure 10. Ternary Diagram. The ternary diagram relates sediment composition to provenance type (Adapted from Dickinson and Suczek, 1973).

By using ternary diagrams showing the relative framework ratios of

monocrystalline quartz, feldspars (potassium feldspar as well as plagioclase), and lithics it is possible to discern the primary provenance type based on Dickinson's work with sandstones. Only framework grains (i.e. $>5 \%$ of the sediment) are considered in the ratio since the interstitial cement or matrix are products of diagenesis (Dickinson and Suczek 1973; Dickinson et al., 1983)

The composition of the $>250 \mu \mathrm{m}$ siliciclastics was determined by identifying each grain and the interpretation was done using the three components used by Dickinson's provenance study: quartz, feldspar (K-feldspar and plagioclase), and lithics. This was done visually using a binocular dissecting microscope. A sample was placed into a plastic tray lined with graph paper to make counts easier. Lithics included all minerals other than quartz and feldspar, volcanics, rock fragments, metamorphics, and 
polycrystalline quartz. Quartz was identified by its lack of cleavage and its transparency. The criteria for feldspar included opaqueness and a $90^{\circ}$ cleavage plane. To aid in the identification Simon and Schuster's Guide to Rocks and Minerals was referenced as well Ward's Geology Collection. Some commonly occurring grains were examined with SEM and EDX to more confidently identify them.

\subsection{Quartz Surface Texture Analysis}

By examining surface microtextures of quartz grains using a scanning electron microscope (SEM) it is possible to differentiate between various transportation mechanisms (Krinsley and Donahue, 1968; Ehrlich and Weinberg, 1970; Culver et al., 1983; Helland and Holmes, 1997; Dunhill, 1998; Bull and Morgan, 2006; Molén, 2014).

Of interest to this study are those transportation mechanisms related to ice. These include sea ice rafted debris (SIRD) and glacial ice rafted debris (IRD).

To analyze the microtexture features on the surface of quartz grains, 30 transparent quartz grains distributed throughout the research time period of 1.9-4.2 Ma were chosen for analysis with the scanning electron microscope (SEM) and energy dispersive $\mathrm{x}$-ray spectroscopy (EDX). Stubs were prepared with the selected quartz grains. The stubs were then coated with gold to a thickness of $9 \mathrm{~nm}$. All the grains were analyzed with EDX to verify that they were quartz $\left(\mathrm{SiO}_{2}\right)$. They were then examined with the SEM. The analysis of quartz surface microtextures is based largely on Molén's (2014) method. This involves identifying the major microtextures and determining the relative history of each. The diagnostic microtextures indicating a glacial environment include mechanical (abrasions, fractures), chemical (weathering, solution, precipitation), and 
crystallization (nodes, embayments, intergrowths, overgrowths, new growth) (Molén, 2014).

Three geological histories are considered: History-0 (fresh), History-1 (recent), and History-2 (old). The abundance of each feature along with its relative age is determined visually.

\section{Results}

A total of 226 samples covering the time period between 1.9 and 4.27 Ma from U1341B were processed to establish a $>250 \mu \mathrm{m}$ MAR record and to create a ternary plot to determine provenance. Surface texture analysis was performed on 30 quartz grains. The results are presented below. 


\subsection{Mass Accumulation Rate}

The mass accumulation rates plotted as a function of time show distinct intervals. Each interval was established by considering average MAR (Figure 11, Table 5) and composition. Some intervals are distinguishable by their low average MAR and weight percent, while others have numerous peaks. There is another clear division around 2.75 Ma (Interval B). The abundance and frequency of peaks substantially increases beginning at 2.7 Ma.

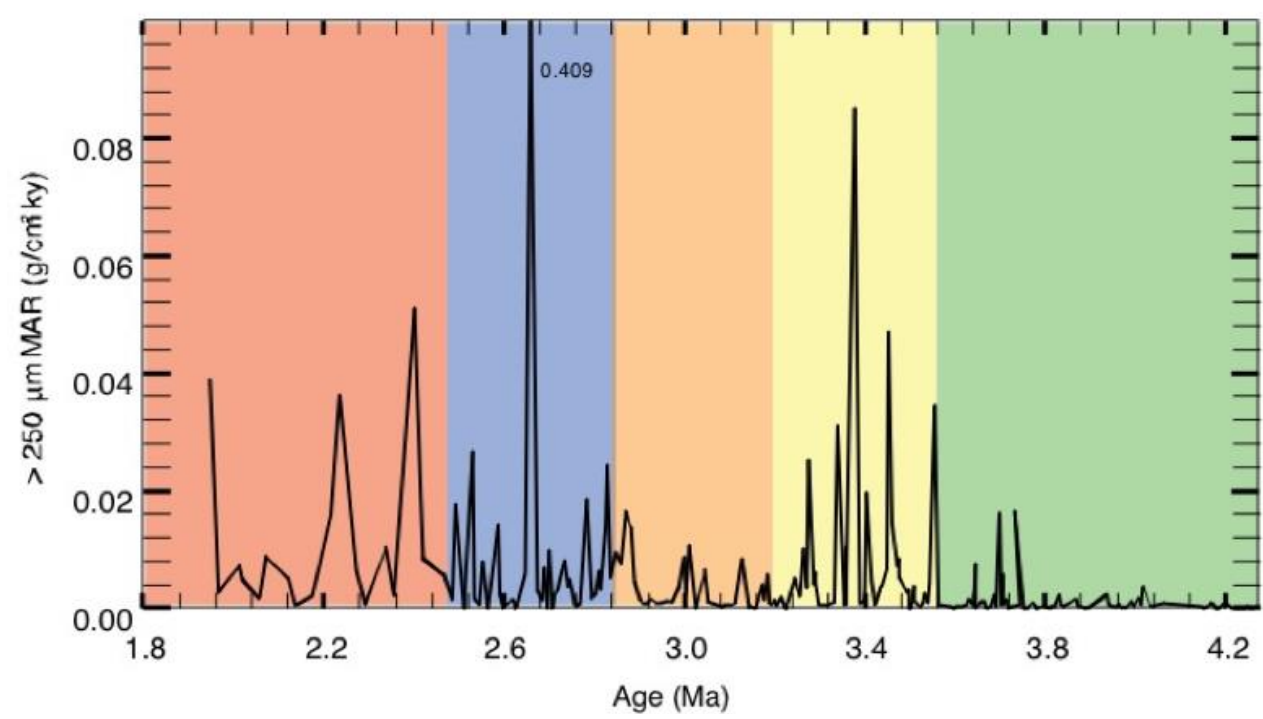

Figure 11. $250 \mu \mathrm{m}$ siliciclastic MAR. This plot shows the 5 intervals based on average MAR values and composition: Interval A (red), Interval B (blue), Interval C (orange), Interval D (yellow), and Interval E (green).

The MAR for the medium to coarse siliciclastic fraction range from 0 to 40.9 $\mathrm{g} / \mathrm{cm}^{2} / \mathrm{ky}(0-0.0116 \mathrm{wt} \%)$. The greatest MAR value occurs at $2.66 \mathrm{Ma}(\sim 378.5 \mathrm{mbsf})$. The following descriptions are from the oldest to the youngest part of the record (Table $5)$. 
Table 5

$\operatorname{MAR} \operatorname{Summary}\left(\mathrm{g} / \mathrm{cm}^{2} / \mathrm{ky}\right)$

\begin{tabular}{lccccc}
\hline & Interval A & Interval B & Interval C & Interval D & Interval E \\
\hline Ages (Ma) & $1.95-2.49$ & $2.49-2.97$ & $2.97-3.19$ & $3.19-3.53$ & $3.53-4.27$ \\
Avg > 250 $\boldsymbol{\mu ~ m ~ M A R ~}$ & 0.011 & 0.013 & 0.003 & 0.008 & 0.001 \\
Std Dev & 0.014 & 0.019 & 0.003 & 0.015 & 0.003 \\
& & & & & \\
Max > 250 $\boldsymbol{\mu m ~ M A R ~}$ & 0.051 & 0.409 & 0.011 & 0.085 & 0.017 \\
Min> 250 $\boldsymbol{\mu m}$ MAR & 0.001 & 0.000 & 0.000 & 0.000 & 0.000 \\
\# of Samples & 20 & 102 & 27 & 45 & 79 \\
\hline
\end{tabular}

Interval E: There is essentially no or very low occurrence of $>250 \mu \mathrm{m}$

siliciclastics; the oldest part of the record, from 3.6 to $4.27 \mathrm{Ma}$, and the $\sim 3.22$ to $2.67 \mathrm{Ma}$ interval similarly have very little to none. The maximum MAR value for this interval is $0.085 \mathrm{~g} / \mathrm{cm}^{2} / \mathrm{ky}$.

Interval D: Following this period of low MAR values, there is a sudden increase at 2.66 Ma that continues until the end of the record at $1.94 \mathrm{Ma}$

Interval C: This interval is characterized by a low average MAR of 0.003

$\mathrm{g} / \mathrm{cm}^{2} / \mathrm{ky}$. The maximum MAR value for this interval is only $0.011 \mathrm{~g} / \mathrm{cm}^{2} / \mathrm{ky}$.

Interval B: 2.75 Ma falls within this interval. The abrupt increase in MAR occurs at $\sim 2.66 \mathrm{Ma}$ where the maximum MAR value of $0.409 \mathrm{~g} / \mathrm{cm}^{2} / \mathrm{ky}$ occurs.

Interval A: Has a moderate average MAR of $0.011 \mathrm{~g} / \mathrm{cm}^{2} / \mathrm{ky}$.

\section{Interval A: 1.95 to $2.49 \mathrm{Ma}$}

Interval $\mathrm{A}$ is composed of samples ranging in age from 1.95 to 2.49 Ma. This interval contains the youngest samples. 


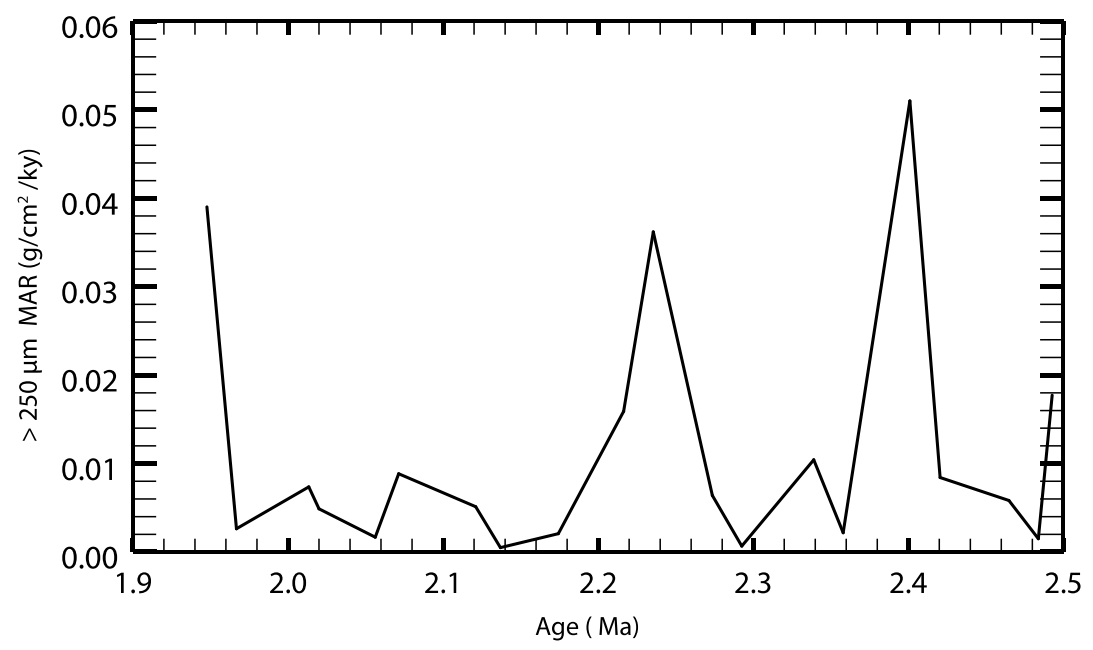

Figure 12. Interval A MAR. This figure shows Interval A, which ranges in age from 1.95 to $2.49 \mathrm{Ma}$. The average $250 \mu \mathrm{m}$ siliciclastic MAR values are relatively high.

The average weight percent of $>250 \mu \mathrm{m}$ siliciclastics is 0.054 . This is second highest of the intervals. The average MAR value is $0.011 \mathrm{~g} / \mathrm{cm}^{2} / \mathrm{ky}$. There are three distinct increases in abundance during this time period shown in Figure 10. Each increase in abundance includes a distinct increase in MAR that is 2 to 3 times the average within the interval. The first occurs from 1.97 to $2.14 \mathrm{Ma}$, the second at 2.14 to $2.29 \mathrm{Ma}$, and the last at 2.29 to $2.48 \mathrm{Ma}$. The increase lasts $17.03 \mathrm{ky}, 15.56 \mathrm{ky}$, and $19.13 \mathrm{ky}$ respectively.

\section{Interval B: 2.49 to $2.97 \mathrm{Ma}$}

Interval B is composed of samples ranging in age from 2.49 to 2.97 Ma shown in Figure 13. This interval has one large spike at 2.66 Ma with a MAR at 0.409 , which is significantly larger than other values within the interval and in any other interval. 


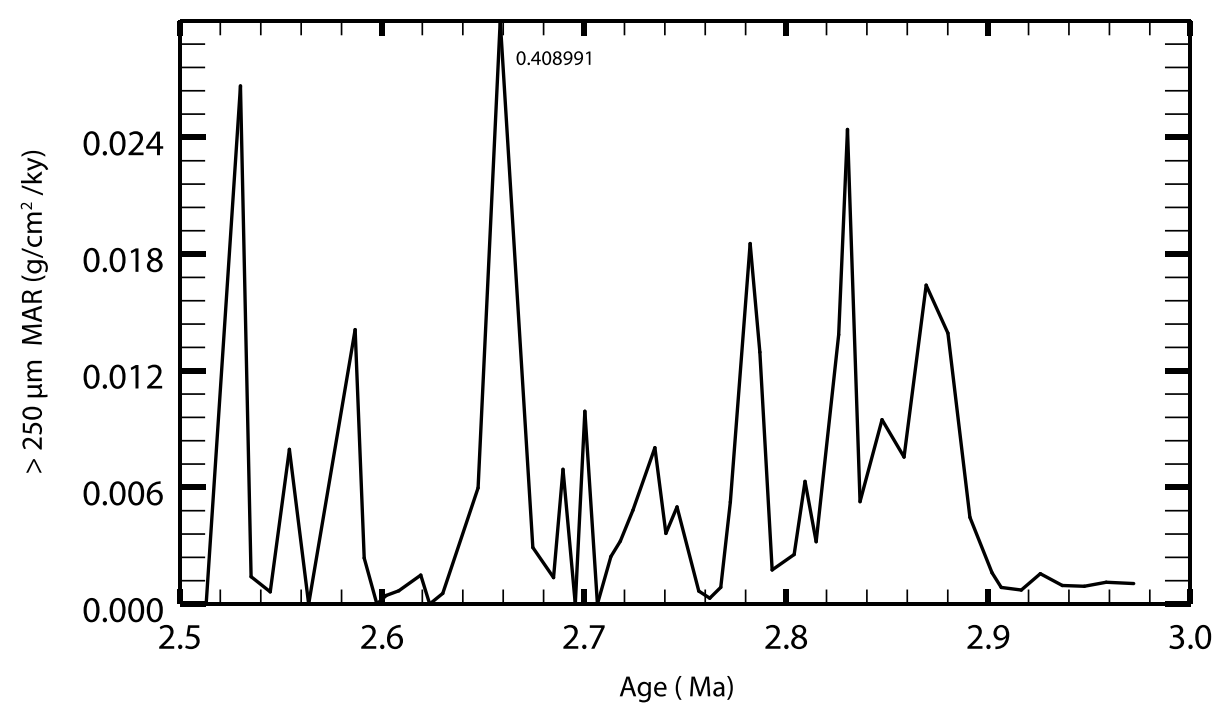

Figure 13. Interval B MAR. Interval B that covers the period from 2.49 to 2.97 Ma. It is characterized by high average $250 \mu \mathrm{m}$ siliciclastic MAR values.

The average weight percent of $>250 \mu \mathrm{m}$ siliciclastics is 0.064 and the average MAR value is $0.013 \mathrm{~g} / \mathrm{cm}^{2} / \mathrm{ky}$. This is the largest average weight percent and MAR among the intervals and was the only one to contain a pebble (weight not shown in weight percent and MAR plots) shown in Figure 14. There are eight increases in abundance within this interval.

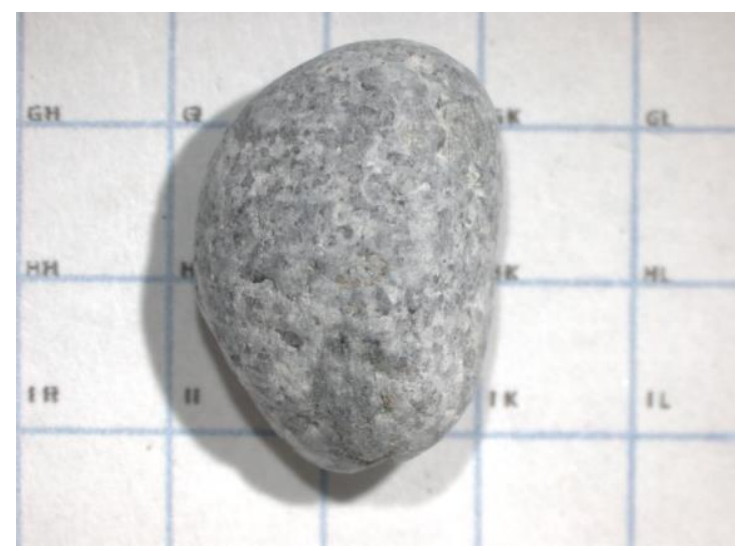

Figure 14. Pebble from Interval B. This is a picture of the only pebble found in U1341B sediment in the study period (Photograph by author). 


\section{Interval C: 2.97 to $3.19 \mathrm{Ma}$}

Interval $\mathrm{C}$ is composed of samples ranging in age from 2.97 to 3.19 Ma shown in Figure 15.

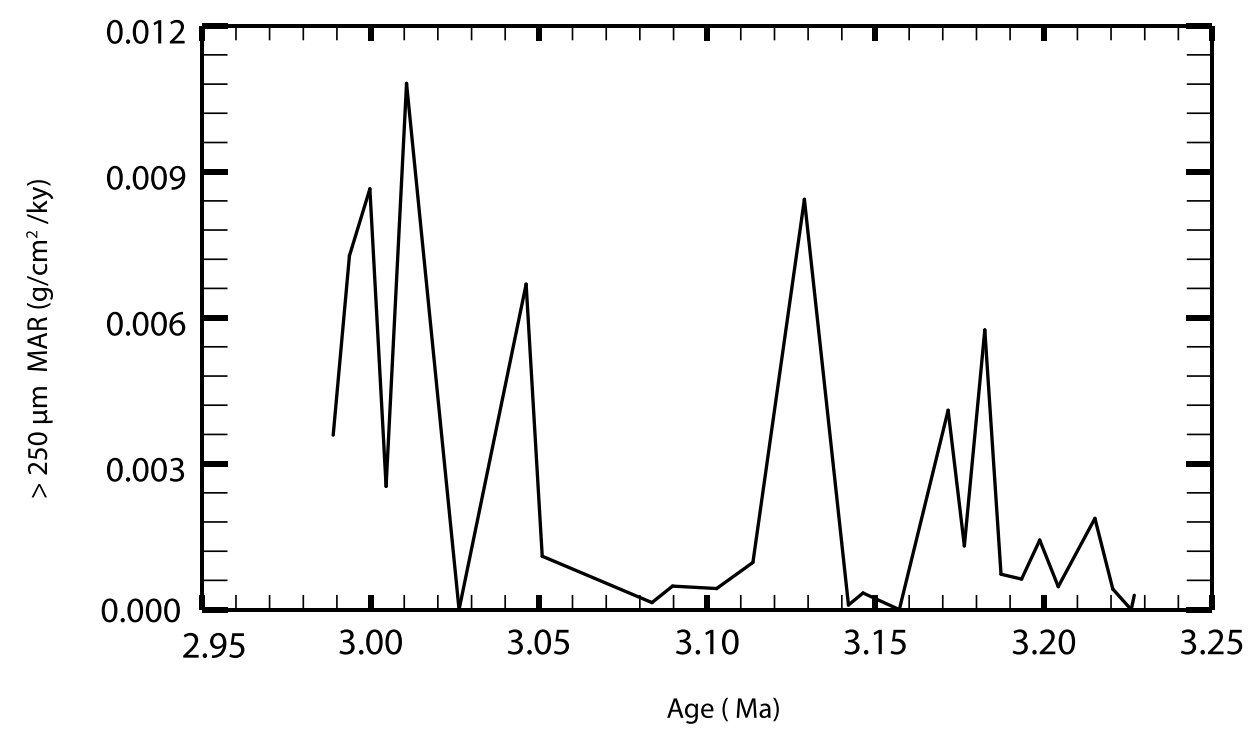

Figure 15. Interval C MAR. Interval C, which ranges from 2.97 to 3.19 Ma. This period has low average $250 \mu \mathrm{m}$ siliciclastic MAR values.

The average weight percent of $>250 \mu \mathrm{m}$ siliciclastics is 0.013 . This is the second lowest average weight percent among the intervals. This interval has a consistently fairly low level of MAR. The average MAR value is $0.003 \mathrm{~g} / \mathrm{cm}^{2} / \mathrm{ky}$. It occurs between two intervals with relatively high average weight percent and MARs.

\section{Interval D: 3.19 to $3.53 \mathrm{Ma}$}

Interval D is composed of samples ranging in age from 3.19 to 3.53 Ma shown in Figure 16. 


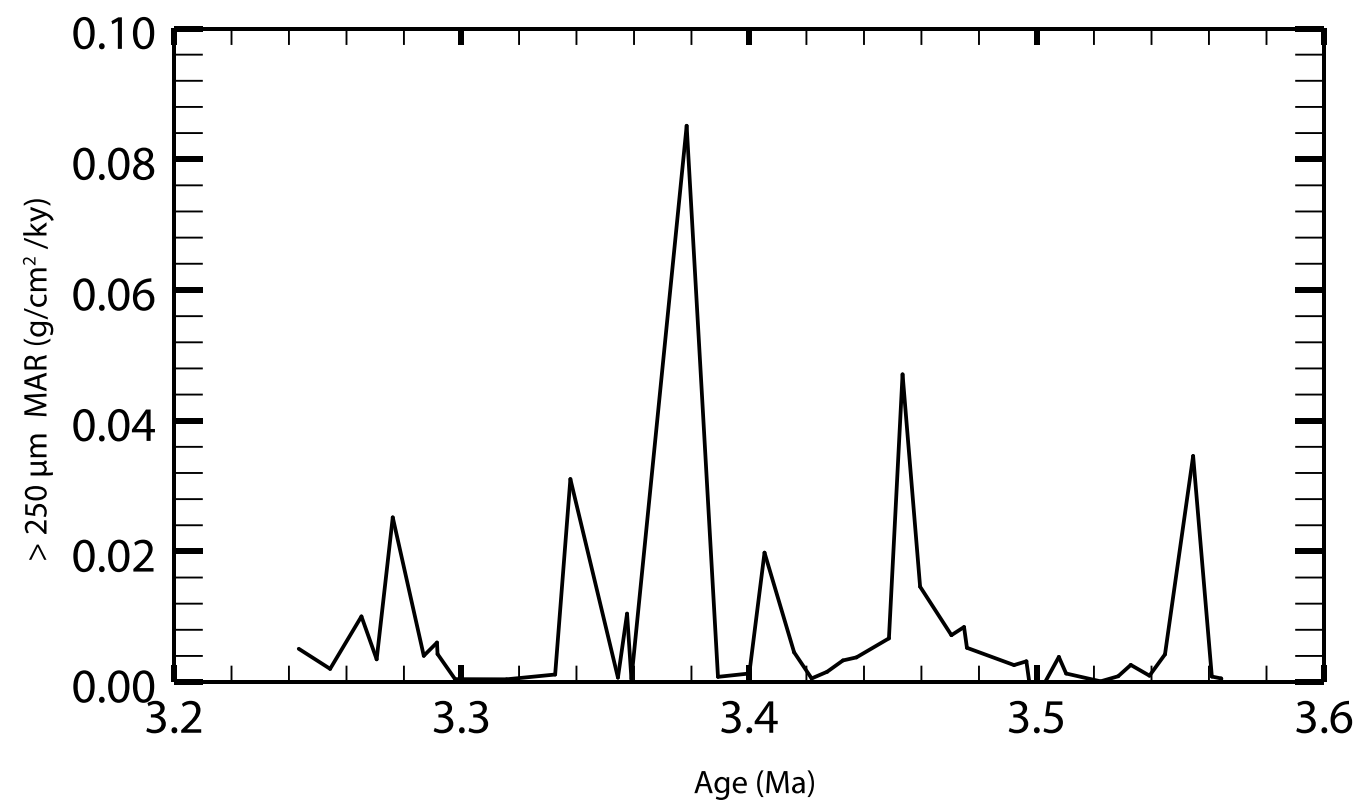

Figure 16. Interval D MAR. Interval D covers the period from 3.19 to $3.53 \mathrm{Ma}$. This interval is the first to show a moderate abundance of $250 \mu \mathrm{m}$ siliciclastic MAR values.

The average weight percent of $>250 \mu \mathrm{m}$ siliciclastics is 0.045 . This is the first interval with a major presence of $>250 \mu \mathrm{m}$ siliciclastics. The average MAR value is $0.008 \mathrm{~g} / \mathrm{cm}^{2} / \mathrm{ky}$.

\section{Interval E: 3.53 to $4.27 \mathrm{Ma}$}

Interval $\mathrm{E}$ is composed of samples ranging in age from 3.53 to $4.27 \mathrm{Ma}$ shown in Figure 17. This interval has the oldest samples. This interval is characterized by having the lowest average weight percent of $>250 \mu \mathrm{m}$ siliciclastics at 0.011 and the lowest average MAR values at $0.001 \mathrm{~g} / \mathrm{cm}^{2} / \mathrm{ky}$. 


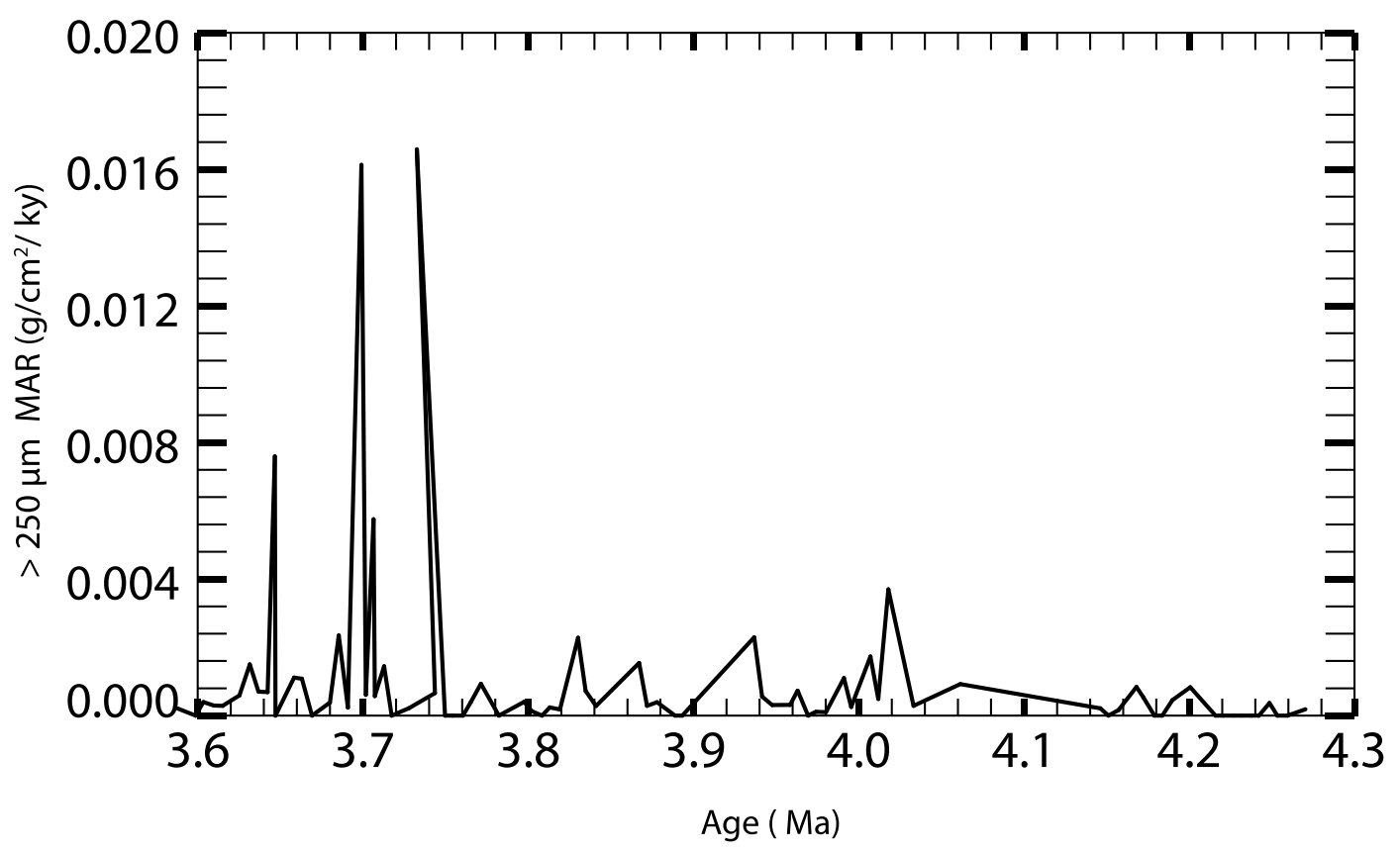

Figure 17. Interval E MAR. Interval $\mathrm{E}$ ranges from 3.5-4.3 Ma. This interval is characterized by low average $250 \mu \mathrm{m}$ siliciclastic MAR values.

\subsection{Provenance/QFL Diagram}

Following Dickinson and Suczec's (1979) use of a ternary diagram to plot the three dominant compositional groups: monocrystalline quartz, feldspar, and lithics in the samples to determine provenance, a QFL diagram was plotted with the grain counts (Figure 18). 


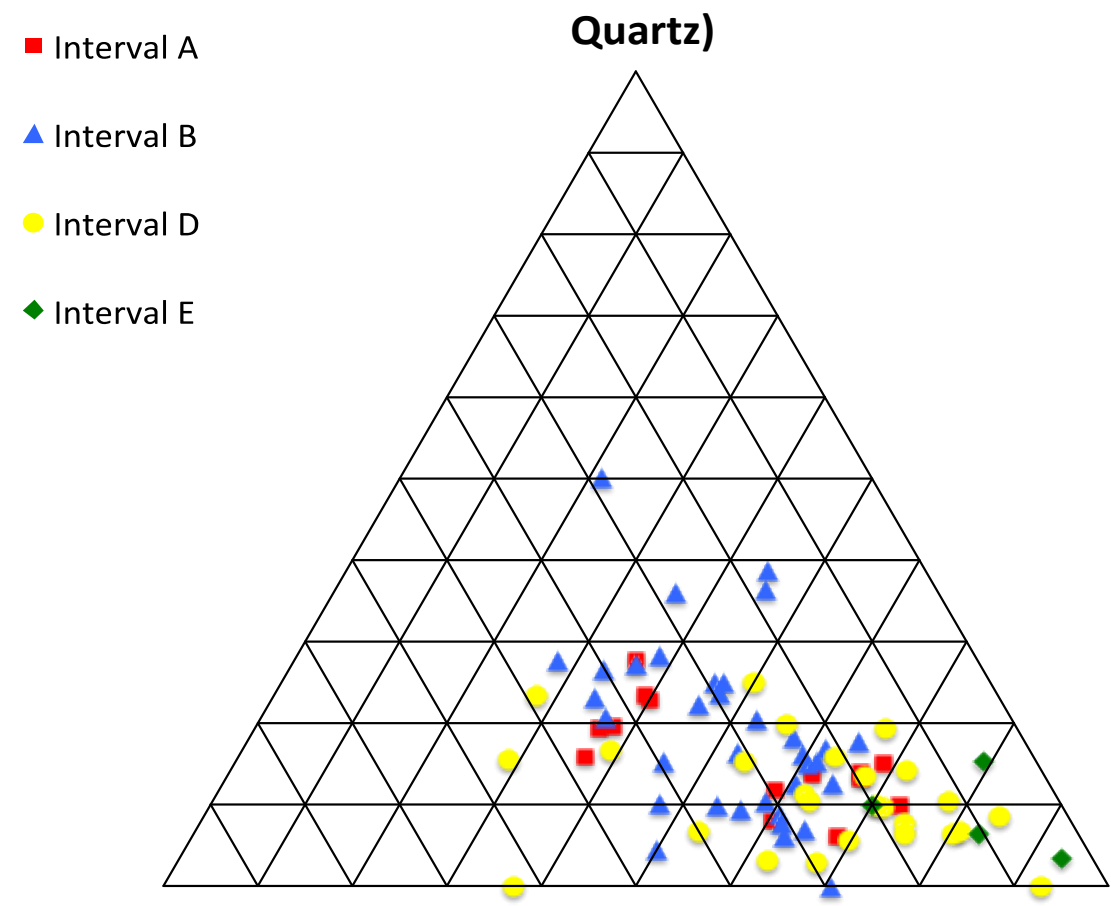

\section{Feldspar)}

\section{Lithics)}

Figure 18. QFL Ternary Diagram. The older samples in Intervals D and E are concentrated near the lithics, whereas the younger Intervals A and B are more centered.

By highlighting each of the intervals within the QFL diagram, a trend from the oldest sediment to the youngest can be detected. The oldest samples (intervals D and E) dominant the lower left of the ternary plot indicating a high percent of lithics and relatively low quartz and feldspar. The younger samples (intervals A and B) still have a high degree of lithics with respect to quartz and lithics, but less than that of the older intervals (D and E). The source of intervals D and E is from an undissected arc, whereas intervals A and B are likely from a transitional arc. 


\subsection{Quartz Surface Texture Analysis}

Surface microtexture analysis was performed on 30 quartz grains from site 1341.

Two groups of samples (15 grains in each group) were examined prior to and after 2.75

Ma (Figure 19).

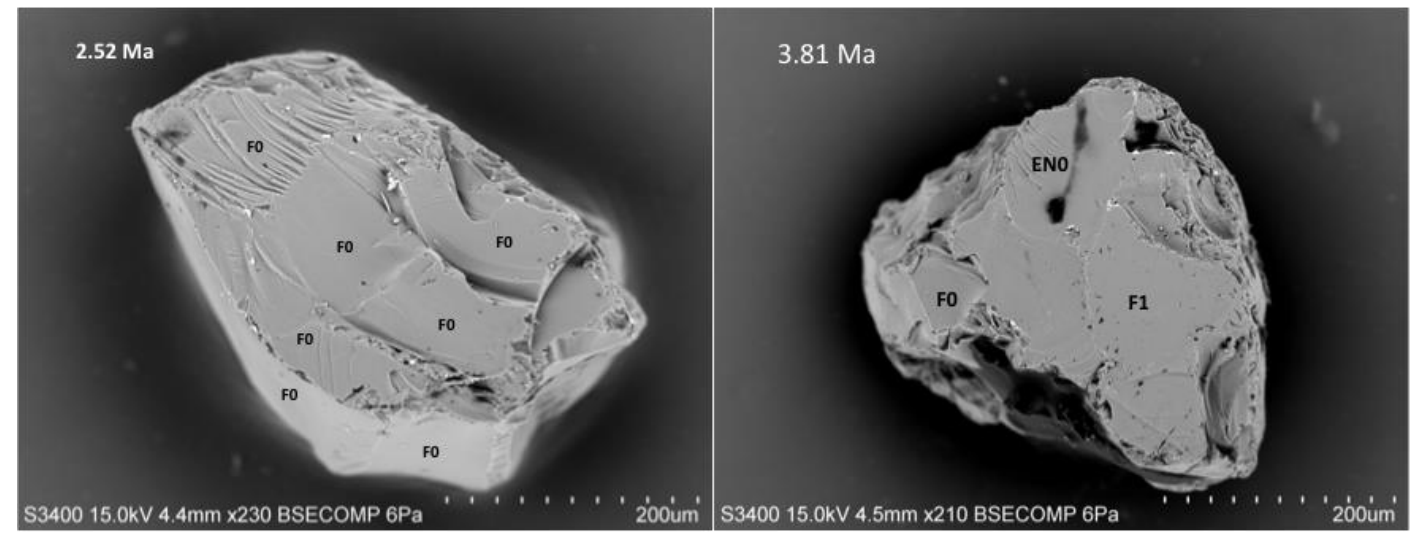

Figure 19. Common Surface Texture Features. Pictured above are some of the most common features of the quartz grains. The samples younger than $2.75 \mathrm{Ma}$ (left) had many fresh fractures, whereas the older samples (right) had a more diverse surface texture (Photographs by author).

Molén's method for defining the surface features of interest was followed. From

his simple approach, the quartz grains from each of the two groups were examined for

large and small fractures, indications of weathering, crystal growth, abrasions, and embayments/nodes (Table 6).

Table 6

Molén's Method

\begin{tabular}{lc}
\hline Symbol & Feature and Extent \\
\hline $\mathrm{F}$ & Large fracture that covers $\geq 20-25 \%$ \\
$\mathrm{f}$ & Small fracture that covers $\sim 5-20 \%$ \\
$\mathrm{~A}$ & Abrasion that covers $\geq 15-20 \%$ \\
$\mathrm{SP}$ & Weathering that covers $\geq 10-15 \%$ \\
$\mathrm{EN}$ & Embayment/nodes that cover $\geq 10-15 \%$ \\
$\mathrm{C}$ & Crystal growth that covers $\geq 5-10 \%$ \\
\hline
\end{tabular}




\section{Discussion}

One of the most important aspects of this thesis is the use of ice rafted debris as a direct indicator of glaciation. The first step is to determine what is, and what is not, ice rafted debris. Size is one of the most critical factors in this determination since grains much larger than $>250 \mu \mathrm{m}$ settle out relatively close to the continental shelf and are therefore transported to Bowers Ridge by ice. Size, however, cannot be the only criterion. Composition, provenance, and surface features are additional important criteria to be considered. Previous work done in the North Pacific and Bering Sea has detected a sharp increase in IRD around 2.6-2.75 Ma (Krissek, 1999; März, 2013).

The plot of $>250 \mu \mathrm{m}$ siliciclastics MAR vs. age reveals the earliest occurrence of significant $>250 \mu \mathrm{m}$ siliciclastics beginning at 3.6 Ma. Abundance increases until it peaks at 3.3 Ma, and then begins to decline. For 600 ky between 3.2 and $2.6 \mathrm{Ma}$, the presence of $>250 \mu \mathrm{m}$ siliciclastics is minimal until it abruptly increases and remains high until the end of the record at 1.9 Ma. There are five intervals based on $>250 \mu \mathrm{m}$ siliciclastic abundance and age that can be discerned from this plot. Another distinguishable division is at 2.6 Ma. From 1.9 to 2.6 Ma the MAR, of $>250 \mu \mathrm{m}$ siliciclastics is relatively and consistently high. In contrast, after $2.6 \mathrm{Ma}$, the $>250 \mu \mathrm{m}$ siliciclastic abundances vary from low to high. Based on the widespread detection from earlier research in the region that onset of continental glaciation began around $2.75 \mathrm{Ma}$, it is reasonable to assume that the $>250 \mu \mathrm{m}$ siliciclastics detected between 1.9 and $2.75 \mathrm{Ma}$ in the U1341 record are indicative of ice-rafting. Therefore the discussion on the record 
will be separated for the interval younger than $2.75 \mathrm{Ma}$ and the interval older than 2.75 Ma (Figure 20).

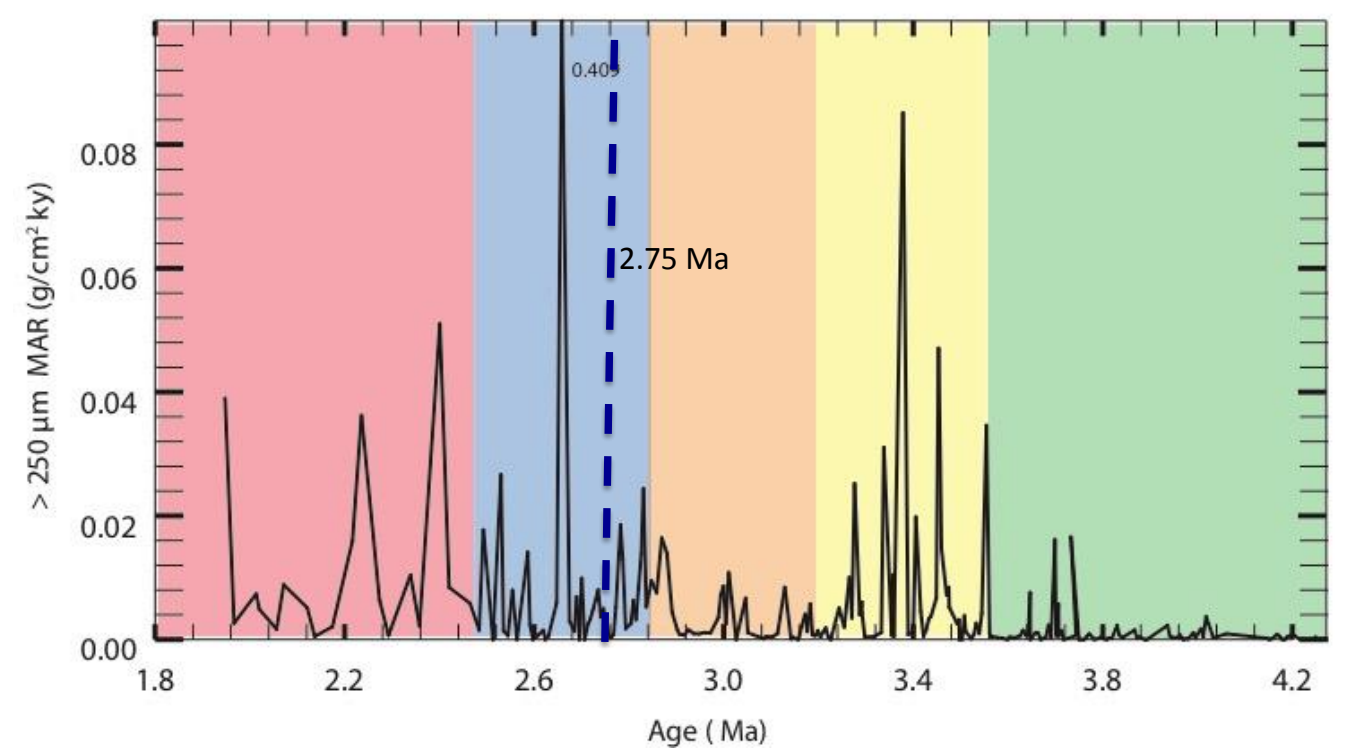

Figure 20. MAR vs Time Plot. This MAR plot is divided into two groups based on age (before and after $2.75 \mathrm{Ma}$ ).

\subsection{Younger than 2.75 Ma}

Previous work from the North Pacific and Bering Sea has detected a sharp increase in IRD around 2.6-2.75 Ma (Haug et al., 1995; Krissek, 1995; März, 2013). It is, therefore, very likely that the $>250 \mu \mathrm{m}$ siliciclastics younger than $2.75 \mathrm{Ma}$ from 1341B are related to ice processes. Additionally, larger dropstones were recovered from U1341 beginning at approximately $2.8 \mathrm{Ma}$. This correlation between the appearance of dropstones and the increase in coarse sand provides further support that the sediment younger than 2.75 Ma was ice-rafted.

The average MAR value for the $>250 \mu \mathrm{m}$ siliciclastic portion younger than 2.75 Ma is $0.015 \mathrm{~g} / \mathrm{cm}^{2} / \mathrm{ky}$. Between 2.66 and $2.75 \mathrm{Ma}$, the MAR values are moderate with a 
few slight increases in abundances. At $2.65 \mathrm{Ma}$, there is a dramatic sudden increase with a value of $0.409 \mathrm{~g} / \mathrm{cm}^{2} / \mathrm{ky}$. After this sudden increase, there are several more increases in abundances and MAR values remain fairly high until the end of the record at 1.9 Ma. The fluctuation in this part of the record includes intermediate data points that lessen the possibility that these fluctuations are merely reflections of the sampling interval (Krissek, 1995).

The MAR record from U1341 was compared to Krissek's (1995) MAR plot from Sites 881, 883, and 887 on ODP Leg 145 (Figure 21). Overall Krissek's MAR values are higher than those for U1341. This is likely the result of the location of the sites. Sites 881 and 883 are both in the Northwestern Pacific near Kamchatka Peninsula. 


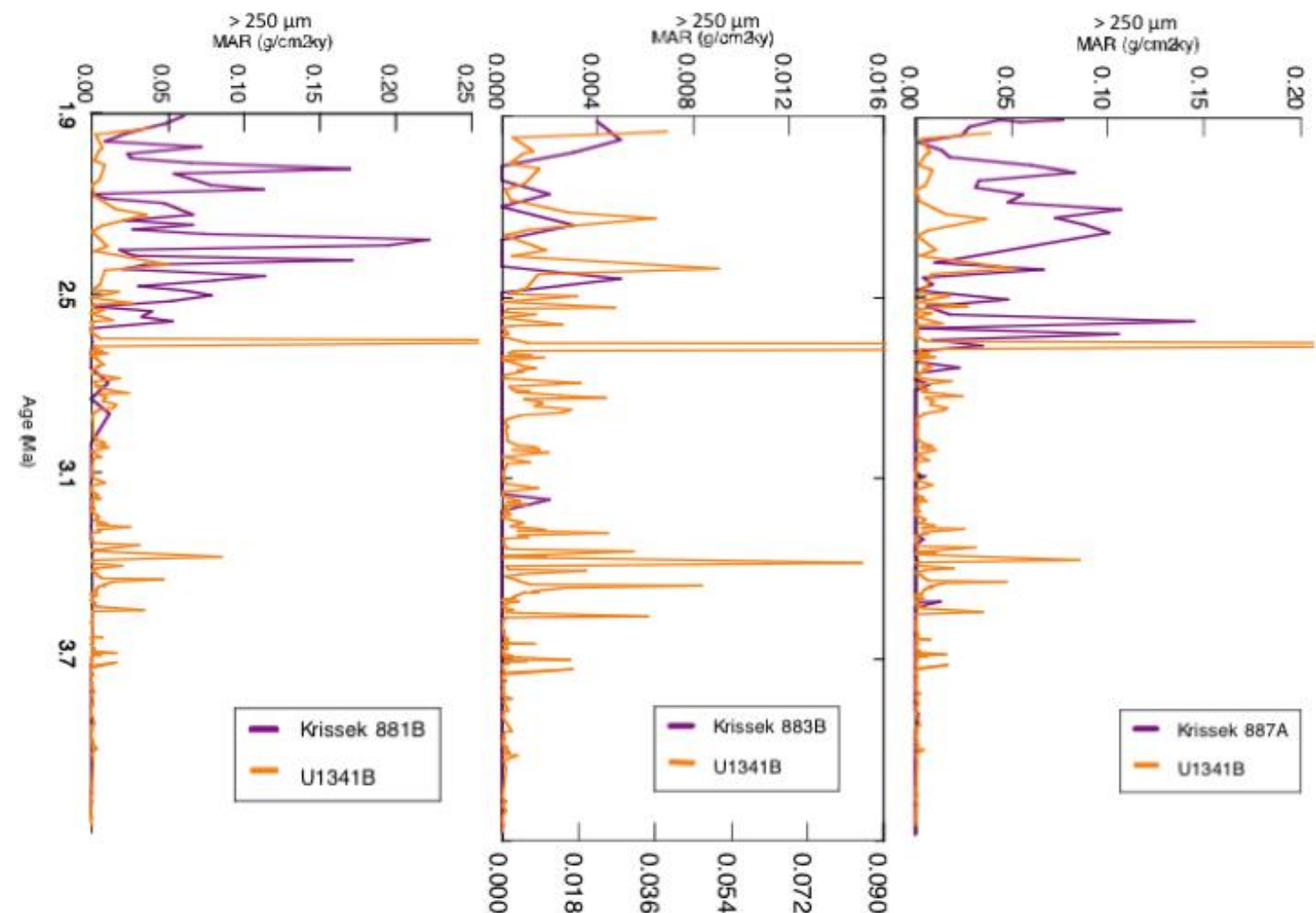

Figure 21. Krissek vs U1341. This figure compares the MAR values for U1341 with Krissek's (1995) data form sites 881, 883, and 887.

The surface circulation in the Bering Sea is a cyclonic gyre. The Bering Slope Current (BCS), which flows along the continental shelf, forms the eastern boundary of the gyre, and the southward flowing Kamchatka Current $(\mathrm{KC})$ forms the western boundary (Cook et al., 2005). The Alaskan Stream flows through passes in the Aleutian Islands and joins the gyre circulation (Cook et al., 2005). Iceberg drift closely follows circulation patterns (Robe, 2012). Icebergs near the continental shelf would flow northward across the shelf carried by the BCS. As they approach Kamchatka Peninsula, the $\mathrm{KC}$ would cause some icebergs to exit the Bering Sea through Kamchatka Strait. Those that were not carried out of the Bering Sea would flow along the Aleutian Islands by the Aleutian North Slope Current (ANC) and past Bowers Ridge (Caissie et al., 2010). 
Site 887 is located near the Patton-Murray Seamounts in the Northeastern Pacific. Icebergs that did not melt after exiting through Kamchakta Strait would travel eastward by the Kuroshio Current and the Sub-Arctic Front before passing over the Patton-Murray Seamounts and moving westward with the Alaskan Stream. Based on these circulation patterns, it seems reasonable that sites 881,883 , and 887 would have more icebergs drift past those locations than U1341. The dominant sources of IRD in the region are the Kurile-Kamchatka margin and the coast along the Gulf of Alaska, so that sites close to those areas would receive the most IRD input compared to more central and southern locations (Krissek, 1995). St. John and Krissek (1999) found that during the Pleistocene the northeast Pacific received a greater supply of IRD than the northwest Pacific. The average MAR values for each site between 1.9 and 2.75 Ma is summarized in Table 7. The U1341 record is similar in many ways to Krissek's.

Table 7

Average MAR Values

\begin{tabular}{lcccc}
\hline Site & U1341 & 881 & 883 & 887 \\
\hline Avg MAR & 0.015 & 0.052 & 0.001 & 0.04
\end{tabular}

Previous work in the North Pacific and Bering Sea has found two primary sources for ice-rafted debris: Kamchatka Peninsula and Alaska. The findings of the major provenance studies are summarized in Table 4. McKelvey et al. (1995) and St. John and Krissek (1999), using data collected from sites 881, 883, and 887 from ODP Leg 145, have determined that IRD from 881 and 883 are most likely from Kamchatka Peninsula, whereas the source of IRD from 887 is probably southeastern Alaska. The St. Elias Mountain's proximity to the coast is a major contributor of sediment to the Gulf of 
Alaska (Reece et al., 2011). Following Dickinson and Suczec (1973)'s use of a ternary diagram to plot the ratio of three dominant compositional groups: monocrystalline quartz, feldspar (K-feldspar and plagioclase), and lithics to determine provenance, a clear provenance and age relationship emerges.

The samples younger than $2.75 \mathrm{Ma}$ are primarily from a transitional arc provenance. The lithics in these younger samples are mostly granites with some schists and volcanic rocks. There was possibly chert in these samples, which would indicate that Kamchatka Peninsula is the source. This would fit with the surface circulation patterns and with what St. John and Krissek (1999) found.

\subsection{Older than 2.75 Ma}

An increase in the abundance of $>250 \mu \mathrm{m}$ siliciclastics MAR vs age plot begin to occur at 3.6 Ma.

The samples older than 2.75 Ma include part of Interval B, and all of Intervals C, $\mathrm{D}$, and $\mathrm{E}$. Intervals $\mathrm{C}$ and $\mathrm{E}$ are distinguishable by their lack of $>250 \mu \mathrm{m}$ siliciclastics. These groups have the lowest average MAR values. Between them is Interval D occurring between 3.27 and 3.55 Ma, which has five increases in abundance in the $>250$ $\mu \mathrm{m}$ MAR record and the second overall highest peak.

The most notable difference between the $>250 \mu \mathrm{m}$ MAR records for U1341 and Krissek's is the earlier presence of several $>250 \mu \mathrm{m}$ siliciclastics peaks in the U1341 record. Between 3.27 and 3.55 Ma, a series of peaks in the $>250 \mu \mathrm{m}$ siliciclastics MAR record occur. These are the oldest presence of $>250 \mu \mathrm{m}$ siliciclastics that appear in the U1341 record. Unlike the younger samples, there are no corresponding peaks between the 
two records. This lack of older peaks in Krissek's record and in other records from the North Pacific (Krissek, 1995; Haug et al., 1999), raises the question as whether this coarse siliciclastic fraction is indicative of early ice-rafting activity or is related to massgravity sedimentation from relatively local sources. Although the Lisiecki and Raymo (2005) stack shows the first significant increase in $\delta^{18} \mathrm{O} \%$ occurring around $3.3 \mathrm{Ma}$, Krissek (1995) did find earlier detections of coarse sand in his record. At site 881, it occurred at 6.6, 5.5, 4.8-4.9, 4.5-4.6, 4.2, 3.9, 3.8, and 3.4-3.7 Ma. Krissek (1995) considered this older coarse sand insignificant since each occurrence was based on a single grain. In contrast, the older samples in the U1341 record have an average number of 21 grains per sample. The range is 0 to 488 grains. At site 883 , Krissek found a single dropstone, which was described as pumice, and therefore not conclusively IRD. At site 887, coarse sand was found at 5.3-5.4, 5.2, 4.9, 4.3-4.4, 3.7-3.9, 3.5-3.6, 3.3-3.4, and 3.1 Ma. Krissek (1995) attributes the coarse sand older than 4.2 Ma to possible tidewater glaciers as suggested by the coeval siliciclastic deposits found in the Yakataga Formation in southeastern Alaska. Krissek does not consider significant glaciation to begin until 2.6 Ma, which is consistent with other work done in the region. Additional considerations involving the composition, provenance, and surface textures will be important in determining whether or not the sediment has been ice-rafted.

A critical first step in determining the mechanism of transport for the older intervals is pinpointing the source of the $>250 \mu \mathrm{m}$ siliciclastics and comparing that to the younger intervals (Figure 22). The older samples (Intervals D and E) dominate the lithics 
corner, indicating an undissected arc provenance whereas the younger samples (Intervals A and B) are more centered and are likely from a transitional arc provenance.

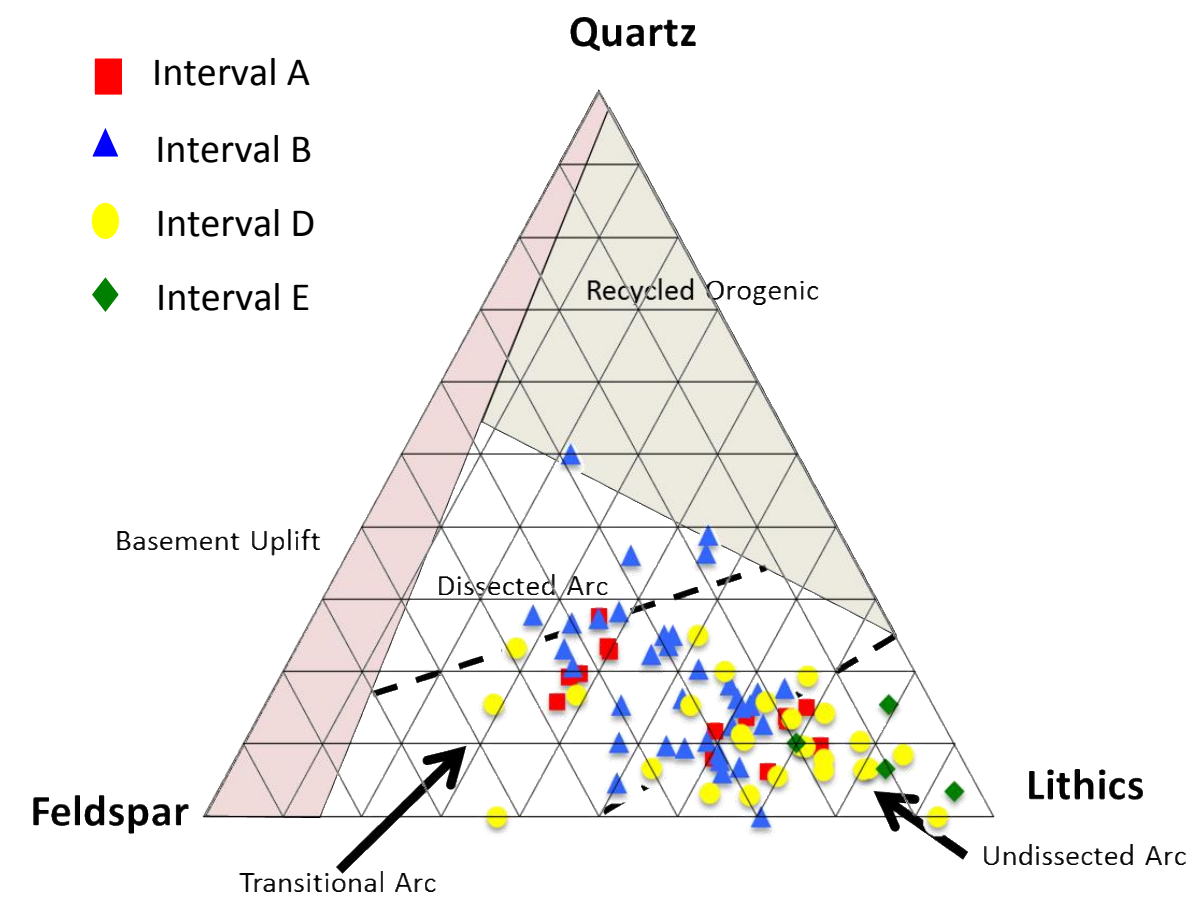

Figure 22. QFL Ternary Diagram. This plot shows the relative ratios of quartz, feldspar, and lithics.

The QFL ternary diagram suggests the provenance for Intervals D and E is an undissected arc. Dickinson and Suczek (1979) define this as an active magmatic arc from either an island arc or continental margin. While nearly all the samples in Interval E and most of Interval D fall within the undissected arc provenance, there is considerable overlap between Interval D and the two younger intervals, A and B. All the intervals are near the lithics corner of the ternary plot. To better understand the compositional differences between the younger and older groups, the lithics were subdivided into three groups: granite, metamorphic, and volcanic, recounted, and organized on a ternary plot 
(Figure 23). There is a clear shift in lithology from volcanics to granites with time. This reinforces the likelihood that there are at least two separate sources for these samples.

\section{Metamoprhic}

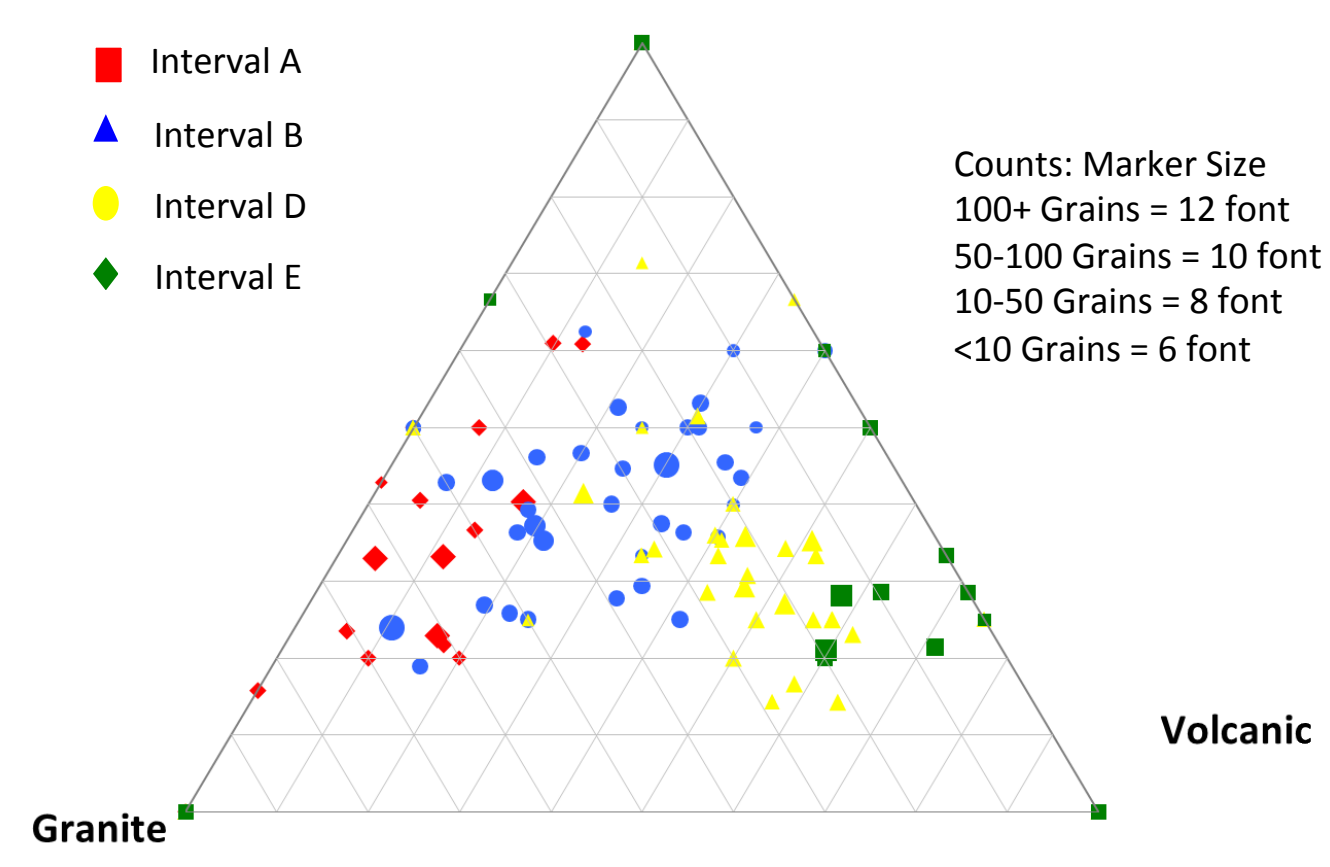

Figure 23. MGV Ternary Diagram. This ternary plot of lithics is divided into Granite, Metamorphic and Volcanic.

Subdividing the lithics highlights the main compositional differences between the younger and older groups. The input of metamorphic clasts seems to remain constant over time. Starting with Interval E, which is clustered in the volcanics corner of the ternary plot, there is a shift over time to the granites corner. This suggests a change in provenance over time. It is clear from the ternary plot that Interval A's $>250 \mu \mathrm{m}$ siliciclastics has a different source than Interval E.

Volcanics dominate Interval E. Interval D has a more varied composition, but with volcanics making up the majority of grains. There are two potential sources of 
volcanics in the region: Bowers Ridge and the Aleutian Island Arc. The nearness of both sources suggests alternate mechanisms unrelated to ice processes could be responsible for the deposition of $>250 \mu \mathrm{m}$ siliciclastics at U1341. One possible mechanism is mass gravity flows, such as turbidity currents. Site U1340, which is adjacent to U1341, has large gaps and coarse deposits that occur at roughly the same time as the earlier abundance of $>250 \mu \mathrm{m}$ at U1341. The seismic profile of U1340 also shows that Bowers Ridge was tectonically active at this time, which could cause turbidity currents. For Bowers Ridge to be the source of the earlier abundance of $>250 \mu \mathrm{m}$ siliciclastics it would need to be subaerially exposed. However, Wanke et al. (2012) found evidence that Bowers Ridge has likely been inactive since the Miocene. Either Bowers Ridge was exposed to subaerial weathering longer than estimated or the $>250 \mu \mathrm{m}$ siliciclastics possibly came from the weathering of rocks exposed in the Aleutian Island Arc. The occurrence of shallow water sponge spicules (Aiello, personal communication) found in the sediment with the $>250 \mu \mathrm{m}$ siliciclastics suggests that Bowers Ridge had not been submerged for as long as previously estimated. There are other possible volcanic sources in Alaska so other factors need to be taken into consideration to determine the origin of the earlier abundance of $>250 \mu \mathrm{m}$ siliciclastics. One consideration is the presence of a terrigenous component in the $>250 \mu \mathrm{m}$ siliciclastics. VanLaningham et al. (2009) found that during glacial periods, Siberia and the region of Alaska drained by the Yukon River were the dominant sources of sediment to the North Pacific. The geology of the Yukon River basin is varied and that variety would be represented in any ice-rafted debris from that region. Quartz in pelagic sediments from the Pacific are typically derived from 
terrigenous or volcanic sources (Rex and Goldberg, 1957). The quartz found among predominately volcanic sediment is usually without inclusions or as quartz phenocrysts, and found in minor amounts (Dickinson and Suzcek, 1979). Looking at just the flux of quartz is a useful way of determining the extent of the contribution of basement uplift sources. Quartz flux was calculated by the following equation:

$$
\text { Quartz flux = \# quartz/wt x DBD x LSR }
$$

This is similar to the MAR calculation where DBD is dry bulk density and LSR is the linear sedimentation rate (Figure 24).
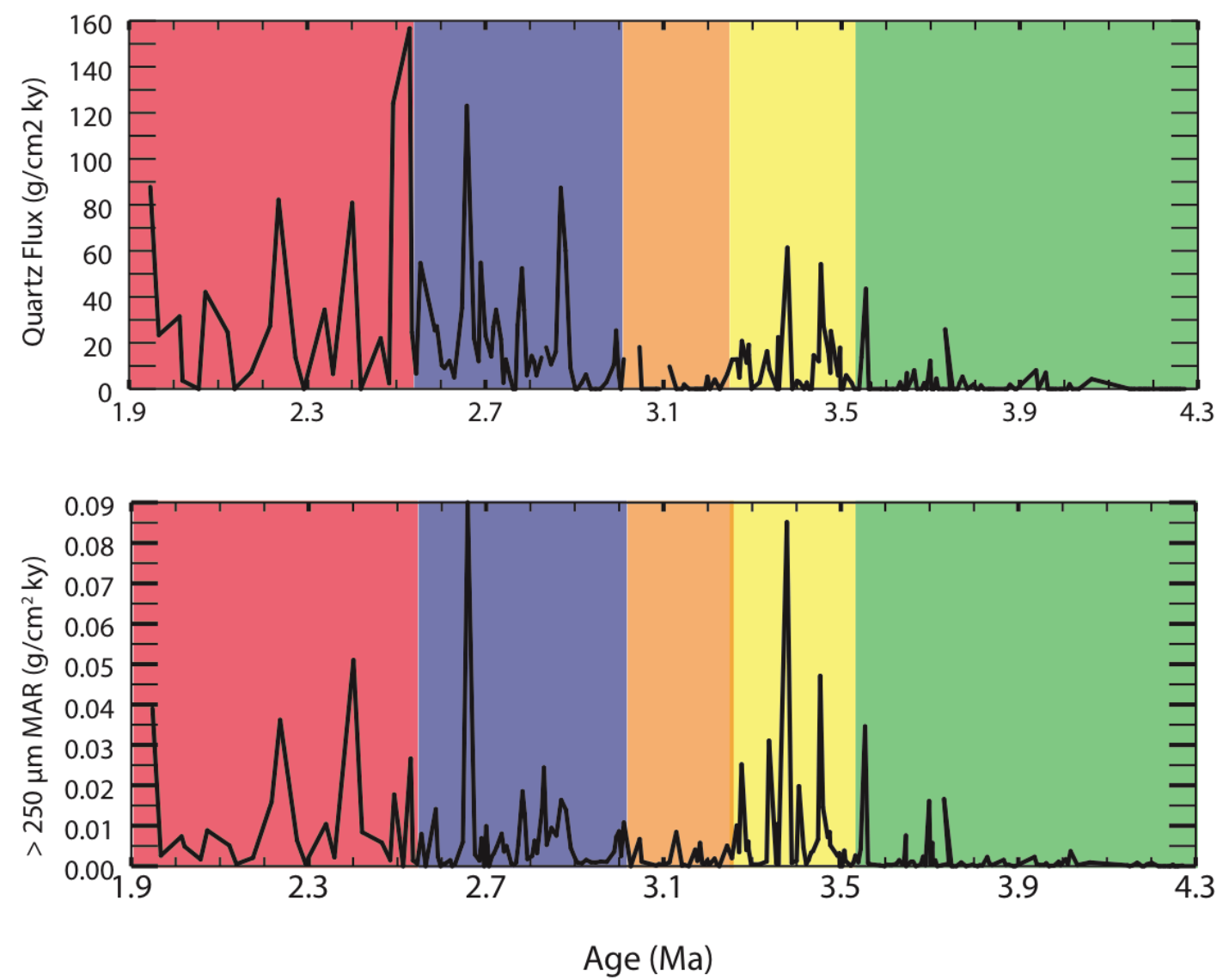

Figure 24. Quartz Flux. The upper plot shows quartz flux over time. A significant increase in quartz flux occurs right at $2.75 \mathrm{Ma}$. The lower plot is the MAR from U1341B. 
From the plot of quartz flux, there is a considerable amount of quartz in the older samples. The average quartz flux for the samples younger than $2.75 \mathrm{Ma}$ is $31.6 \mathrm{~g} / \mathrm{cm}^{2} / \mathrm{ky}$ while the average value for the period between $3.2-3.55 \mathrm{Ma}$ is $11.3 \mathrm{~g} / \mathrm{cm}^{2} / \mathrm{ky}$. The first major peak in the quartz record occurs at $2.75 \mathrm{Ma}$, in agreement with the timing of NHG found in other records (Haug et al., 1995; Krissek, 1995). The amount of quartz in the older samples is not present in comparable amounts to the younger samples, and therefore, it remains unclear how the $>250 \mu \mathrm{m}$ siliciclastics were transported to Bowers Ridge. One last consideration involves examining the surface features of some of the grains for clues.

Quartz is a stable mineral that resists weathering and chemical alteration while also being abundant in potential sediment (Bull and Morgan, 2006). This makes it ideal for studying its surface for clues to how it was transported (Krinsley and Donahue, 1968; Dunhill, 1998; Molén, 2014). Grains transported by glacial ice are distinguishable by surfaces having largely mechanical features such as conchoidal fractures, breakage blocks, and high relief (Dunhill, 1998). Molén (2014) has recently proposed a simpler, and more quantitative, method for evaluating quartz surface microtextures. He reduces the number of features to six and assigns each feature a relative history to indicate how fresh or old the features are compared to the grain's other features. This was done on two groups of 15 quartz grains: younger than $2.75 \mathrm{Ma}$ and older than $2.75 \mathrm{Ma}$. Both groups of samples displayed the same degree of fracturing (Figure 25). The primary difference between the older and younger samples is the degree of weathering. 


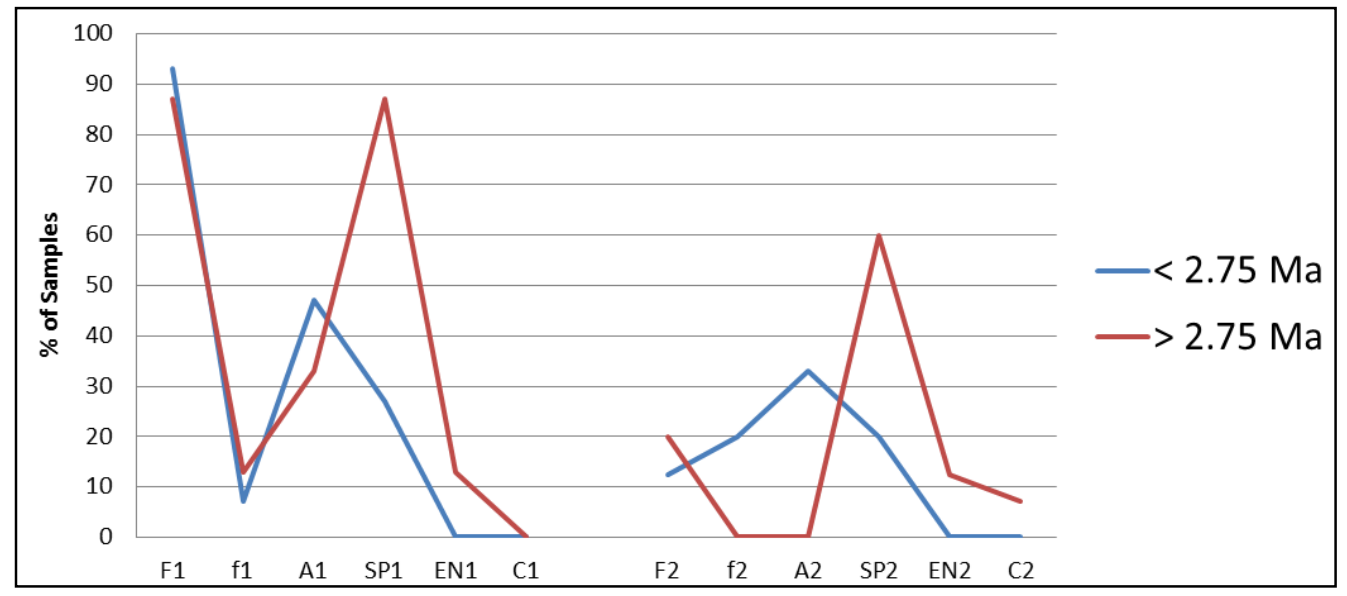

Figure 25. Suface Texture Analysis. This plot summarizes the surface features of quartz grains following Molen (2014)'s simple quantitative approach.

They were dominated by large fractures with some small fractures and abrasion.

The primary difference between the two groups was the extent of weathering. The younger samples were fresh whereas the older samples had considerably more solution/precipitation features indicating an older history (Figure 26). 


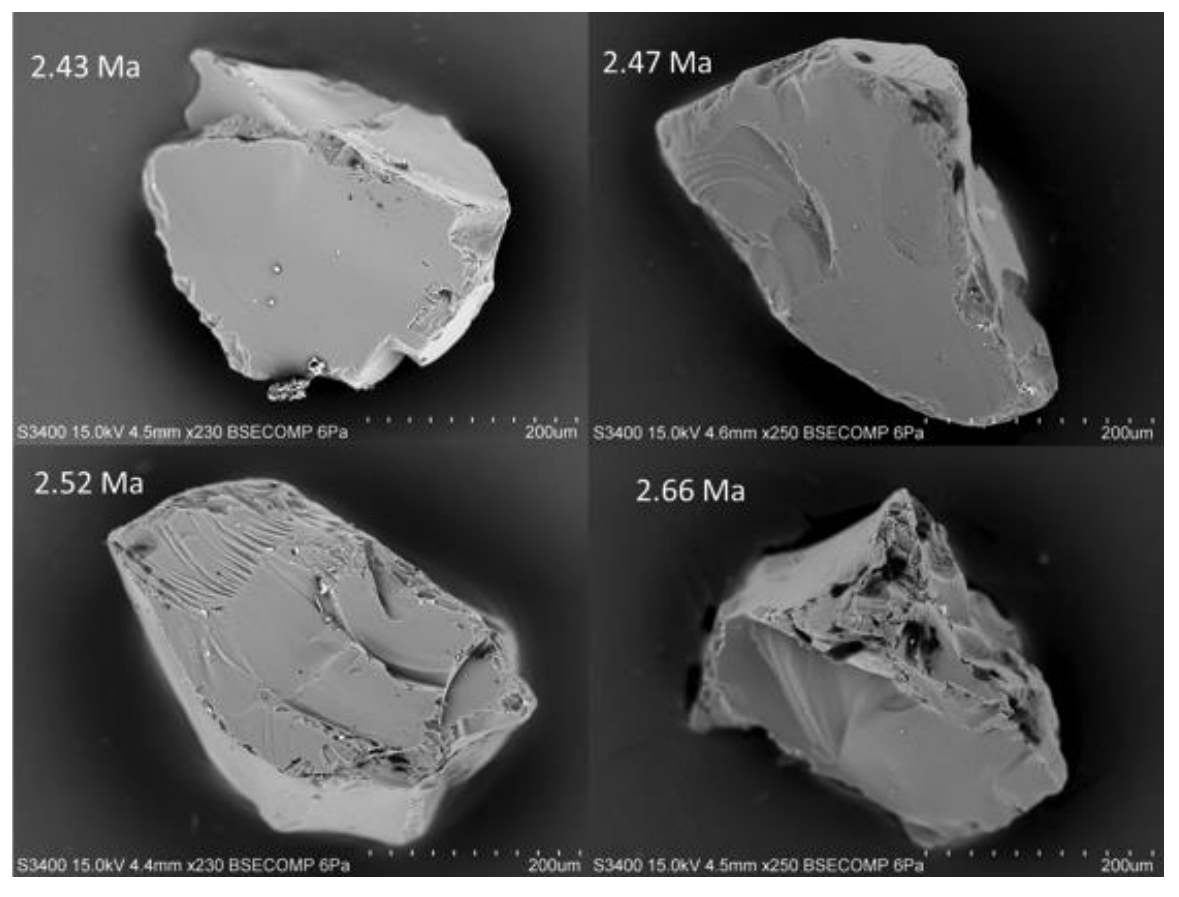

Figure 26. Surface Texture Features Younger than 2.75 Ma. The dominant surface textural features are fresh fractures (Photographs by author).

It is clear that the younger group were transported by ice. It also seems likely that the older group or a portion of them was also transported by ice (Figure 27). There are more solution/precipitation features in these older samples than in the younger quartz grains. 


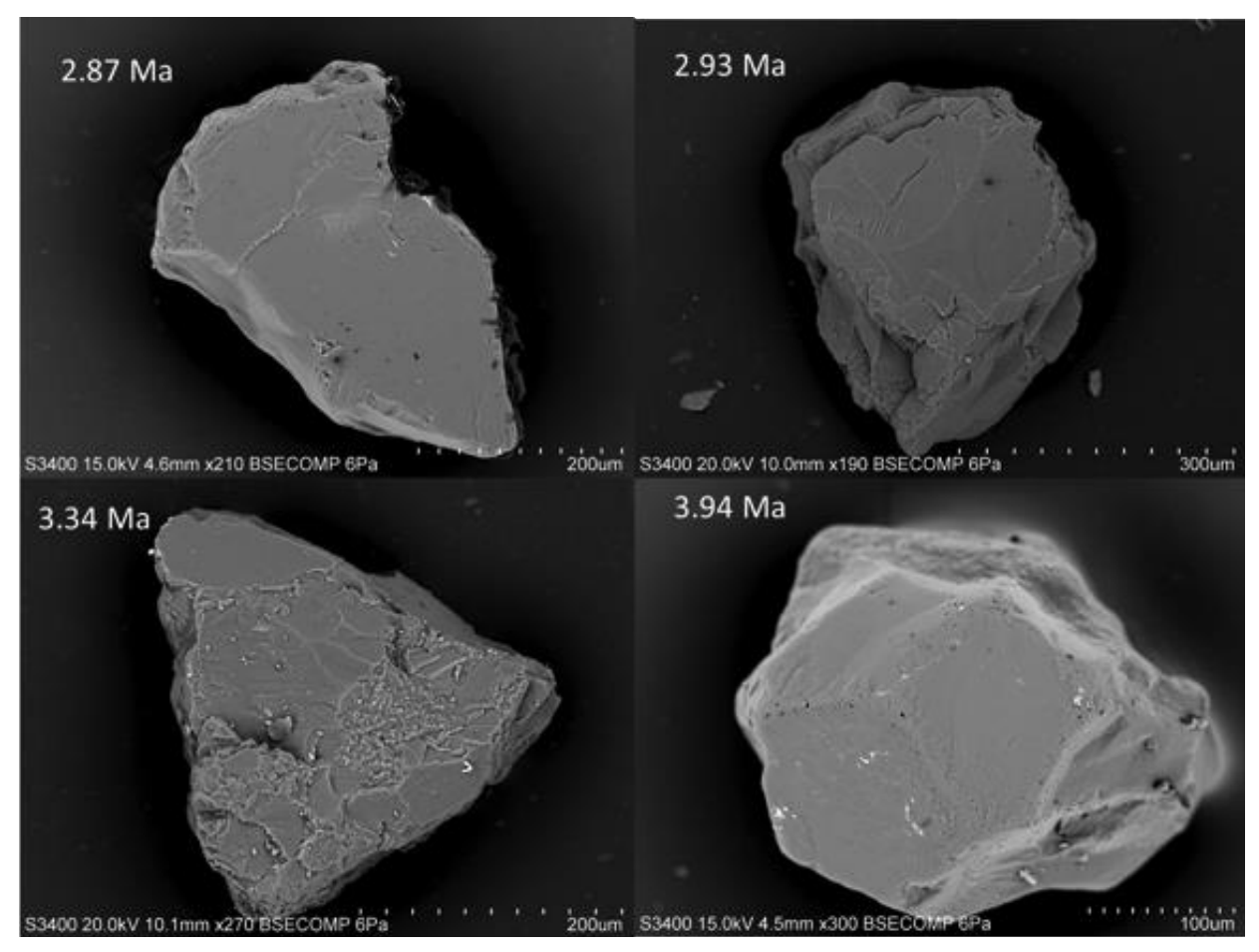

Figure 27. Surface Texture Features Older than 2.75 Ma. The fractures are less fresh than the younger quartz (Photographs by author).

Is it possible the $>250 \mu \mathrm{m}$ in the samples older than $2.75 \mathrm{Ma}$ are from the Aleutians or the result of local re-sedimentation from Bowers Ridge?

\subsection{Hypotheses}

There a number of possible explanations to account for the presence of $>250 \mu \mathrm{m}$ siliciclastics before $2.75 \mathrm{Ma}$.

1. The petrographic analyses indicate that the oldest samples from Intervals D and E are dominated by volcanic clasts. The QFL ternary plot indicates an undissected arc provenance. There are two potential sources of volcanic rocks to this region of the Bering Sea: the Aleutian Island arc and the Bering Sea basalt province (März et al., 2013). However, the closest potential source is Bowers Ridge is a 
submerged magmatic arc that extends north from the Aleutian Island arc. This suggests that the $>250 \mu \mathrm{m}$ siliciclastics could be the result of local resedimentation of Bowers Ridge or the result of local tectonic activity.

A recent paper by Brigham-Grette et al. (2013) supports this hypothesis. The authors present a paleoclimatic record from the Siberian Arctic that challenges the notion that the conditions prior to $2.75 \mathrm{Ma}$ were conducive for glaciation. The evidence that they present suggest that climate from 3.6- $2.2 \mathrm{Ma}$ was as warm as during the Holocene, and therefore, too warm for glaciation to persist.

Horikawa et al. (2015) using neodymium $(\mathrm{Nd})$ and lead $(\mathrm{Pb})$ isotope data from detrital material from Site U1341 found that prior to Marine Isotope Stage (MIS) M2 about 3.32 Ma the terrigenous component of the sediment was likely from local (Aleutian Island) sources. This would support the interpretation that the $>250 \mu \mathrm{m}$ siliciclastics described in this study is similarly from local volcanic sources. However, Horikawa et al. (2015) did find pulses of terrigenous sediment with Alaskan provenance during this time interval. Two of these pulses occur at 3.319 Ma and 3.55 Ma. It is interesting to observe that the pulses have similar ages as the increase in $>250 \mu \mathrm{m}$ siliciclastics abundances at $3.33 \mathrm{Ma}$ and $3.55 \mathrm{Ma}$ found in this study (Figure 28). The more negative values of detrital $\varepsilon_{\mathrm{Nd}}$ indicate an Alaskan provenance, whereas the higher values suggest a local Aleutian source. Two of the Alaskan pulses in the detrial $\varepsilon_{\mathrm{Nd}}$ record occurring prior to 2.75 Ma align with two of the increases in $>250 \mu \mathrm{m}$ MAR abundances (yellow). 
a

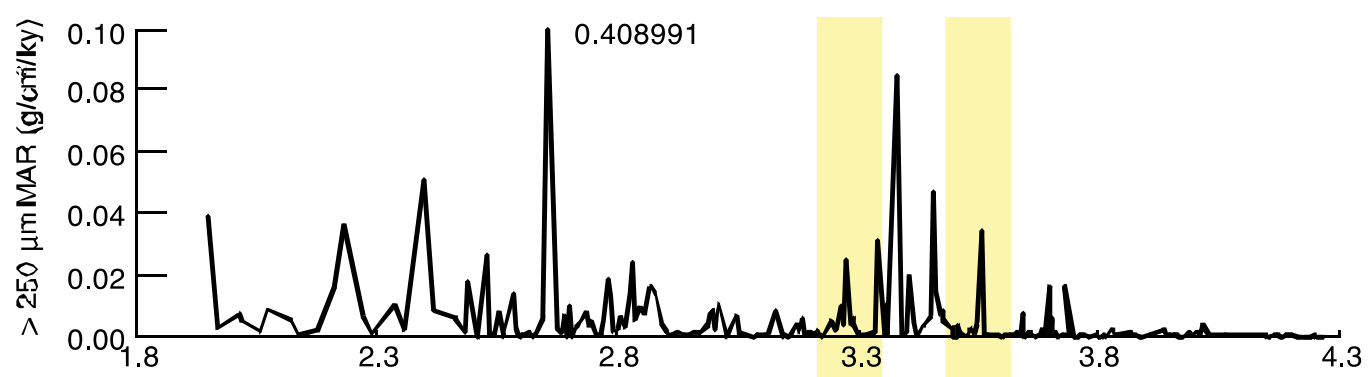

b

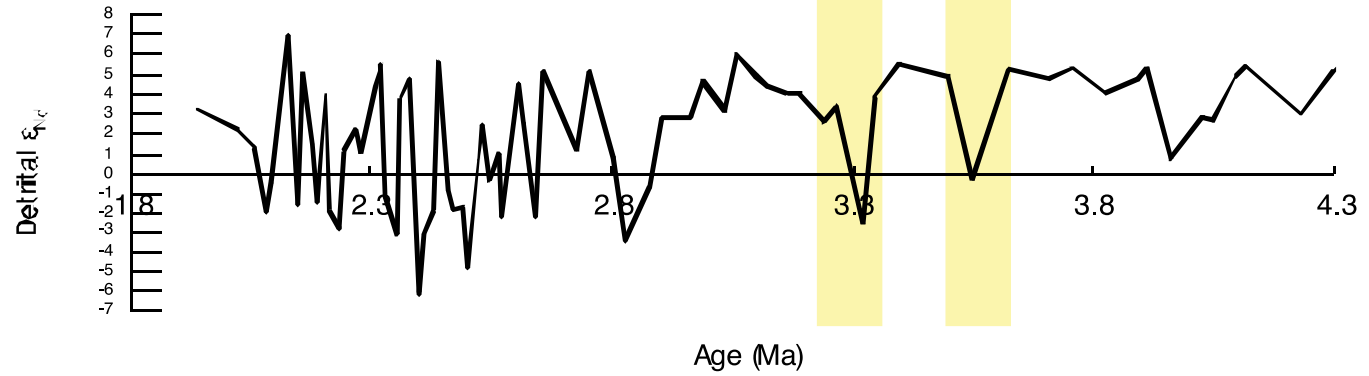

Figure 28. Detrital $\varepsilon N d$ values. Detrital $\varepsilon N d$ values from U1341B (Horikawa et al., 2015). (a) shows Horikawa et al.'s (2015) detrital $\varepsilon N d$ values from U1341B (b) compared to the $>250 \mu \mathrm{m}$ MAR values from the same site.

A potential concern with this hypothesis is that for re-sedimentation to occur, Bowers Ridge would still need to have been sub-aerially exposed. The timing of the $>250 \mu \mathrm{m}$ siliciclastics found at U1341 occurs after Bowers Ridge was submerged according to Wanke et al. (2012) and Cooper et al. (2005). So if this sediment is from Bowers Ridge, then the previous estimate for its subsidence is off. The authors found that movement of Bowers Ridge had slowed and its volcanic activity had stopped by the end of the Cenozoic. However, the seismic profiles for U1340, a site on Bowers Ridge close to U1341, shows that the ridge was possibly still tectonically active. This could result in slumping and movement of coarse sediments including the $>250 \mu \mathrm{m}$ fraction. Horikawa et al. (2015) using 
neodymium $(\mathrm{Nd})$ and lead $(\mathrm{Pb})$ isotope data from detrital material from U1341 found that prior to Marine Isotope Stage (MIS) M2 about 3.32 Ma the sediment was likely from local Aleutian sources. This would suggest that the $>250 \mu \mathrm{m}$ siliciclastics used in this study are similarly from local sources. Horikawa et al. (2015) did find pulses of Alaskan sediment during this interval. Two such pulses occurred at $3.319 \mathrm{Ma}$ and $3.55 \mathrm{Ma}$. This is close to the increase in $>250 \mu \mathrm{m}$ siliciclastics abundances at $3.33 \mathrm{Ma}$ and $3.55 \mathrm{Ma}$ found in this study.

2. The Pliocene (5.33-2.58 Ma) is an important global climatic time period. The Pliocene was relatively warm and characterized by increased sea surface temperatures (SST) of $3-4^{\circ} \mathrm{C}$, a sea level $10-20 \mathrm{~m}$ higher, a $30 \%$ higher concentration of atmospheric carbon dioxide, and a stronger thermohaline circulation than today (Ravelo et al., 2004; Brierley et al., 2009). A cooling trend can be observed (Figure 29) in the global benthic oxygen isotope stack (LR04) during the Pliocene. A noticeable feature of the $\delta^{18} 0$ record occurs at Marine Isotope Stage (MIS) M2 at $3.3 \mathrm{Ma}$. The sharp change in $\delta^{18} 0$ coincides with an increase in $>250 \mu \mathrm{m}$ siliciclastics abundances at U1341B. This suggests that at least that portion of the $>250 \mu \mathrm{m}$ siliciclastics record is the result of ice-rafting. The gradual cooling was interrupted for a brief warm period in the mid-Pliocene (3.29-2.97 Ma). This is supported by the $>250 \mu \mathrm{m}$ siliciclastics record when abundances are very low. Cooling then continued until intensifying at the Pliocene-Pleistocene boundary around 2.75 Ma in the North Hemisphere (De Schepper et al., 2014). 
a
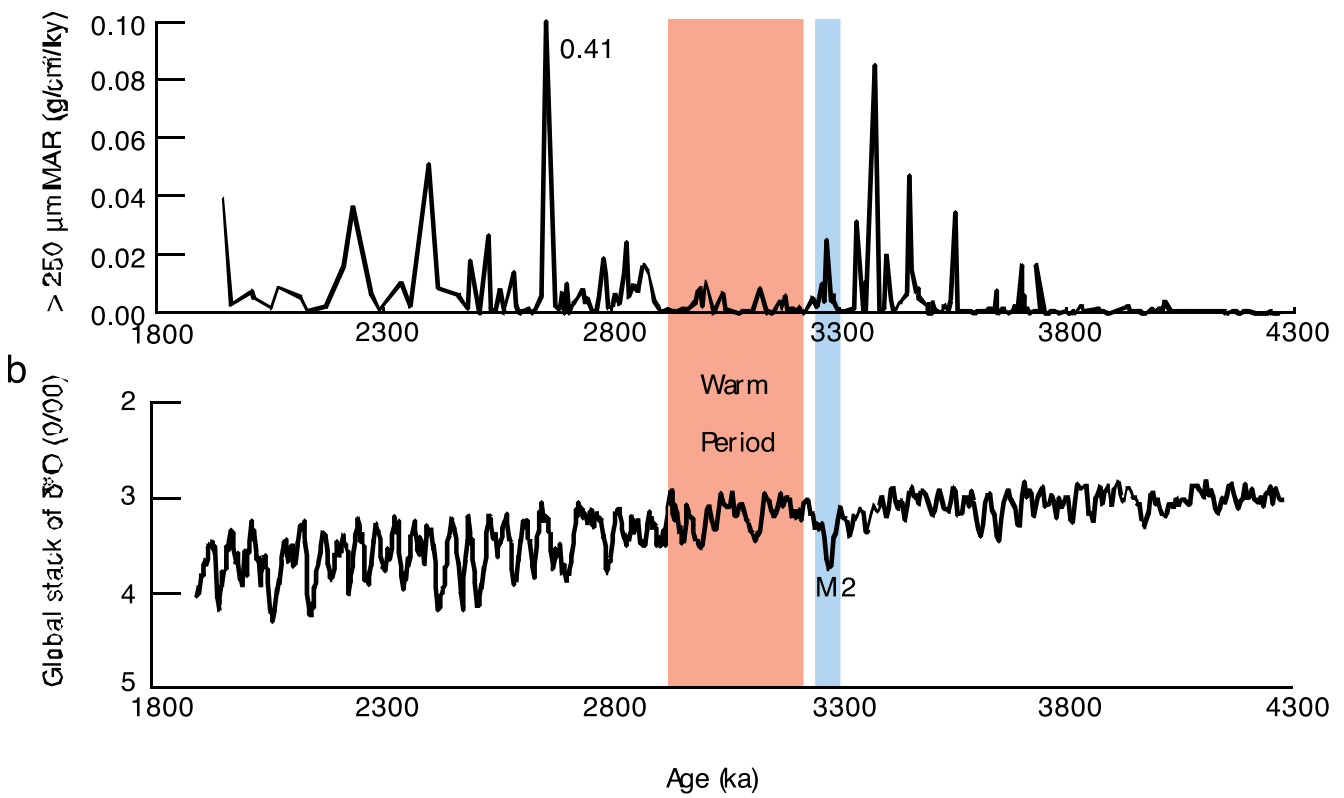

Figure 29. MAR vs Time Plot. Plot from U1341B with the Global Stack of Benthic $\delta 180$ Record (Lisiecki and Raymo, 2005). (a) shows the $>250 \mu \mathrm{m}$ MAR values from U1341B, (b) shows the global stack of benthic $\delta 180$ record from Lisiecki and Raymo (2005).

Krissek (1995) found the early occurrences of IRD at 6.6 and 5.5 Ma, which he attributes to the Yakataga Formation near the Alaskan coast (Lagoe et al., 1993; De Schepper et al., 2014). Following the warm interval during the midPliocene, glaciation intensified and ice sheets became well developed at 2.75 Ma (Krissek, 1995; Reece et al., 2011). It is widely thought that the onset of NHG occurred gradually and in a stepwise manner (Ravelo et al., 2004; Brigham-Grette et al., 2013; De Schepper et al., 2014). Due to the geographic and atmospheric circulation patterns, southwest Alaska experiences conditions favorable to glaciation. For this reason, the IRD prior to 2.75 found in the North Pacific and Gulf of Alaska are thought to be the result of this limited glaciation on coastal 
Alaskan mountains and not an indication of widespread continental glaciation (Prueher and Rea, 2001; Reece et al., 2011; De Schepper et al., 2014). The > 250 $\mu \mathrm{m}$ siliciclastics record from U1341B seems to agree with this overall timing. Arkhipov et al. (1986) found limited glaciers at sea level on Kamchatka Peninsula during the middle Pleistocene. This means that any IRD prior to then was most likely from Alaska. As glaciation became more extensive and moved northward and to Kamchatka Peninsula, it would begin become a source for IRD. This would account for the change in provenance observed at U1341.

3. Another possibility is that the earlier abundance of $>250 \mu \mathrm{m}$ siliciclastics does not indicate the beginning of significant glaciation. Instead they represent ephemeral glaciation that was restricted to the mountainous southeast Alaska.

\section{Conclusions}

1. An important tool in creating a record of ice-rafting for Bowers Ridge was quantifying the amount of $>250 \mu \mathrm{m}$ siliciclastics from marine core sediment and creating a $>250 \mu \mathrm{m}$ concentration vs age plot. While it is not clear that all the $>$ $250 \mu \mathrm{m}$ sediment from the plot was ice-rafted, it elucidated other major processes that contributed to deposition of sediment $>250 \mu \mathrm{m}$ at Bowers Ridge.

2. Using a QFL ternary diagram developed by Dickinson and Suczek (1979) was critical in detecting a change in provenance with time. The samples older than 2.75 Ma were from an undissected arc, whereas the younger samples were from a transitional arc. 
3. The use of microtexture analysis of quartz grains using SEM was useful in detecting diagnostic surface features that indicate ice related transport mechanisms. While there were clear differences in the ages of the samples as indicated by the degree of weathering, both age groups had a preponderance of large and small fractures and abrasions.

4. Whether the coarse siliciclastic component found in U1341 sediments older than 2.75 Ma is the result of ice-related processes or local re-sedimentation from Bowers Ridge is unclear. It is possible that both processes contributed to its deposition at Bowers Ridge.

5. With the exception of Interval D, the samples younger than $2.75 \mathrm{Ma}$ had significantly more coarse siliciclastics than the samples older than $2.75 \mathrm{Ma}$. There were also important compositional differences between samples older and younger than 2.75 Ma. The younger samples had more quartz and granites. In contrast, the majority of the older samples were composed of volcanic rocks.

6. The U1341 MAR record, when compared to other records from the North Pacific and Bering Sea, was in agreement with the timing of NHG onset. The biggest differences between Krissek's (1995) record and U1341 were the amount of coarse sediment found and the peaks detected earlier at U1341. 


\section{REFERENCES}

Aiello, I. W., \& Ravelo, A. C. (2012). Evolution of marine sedimentation in the Bering Sea since the Pliocene. Geosphere, 8, 1231-1253.

Arden, R. S., \& Wigle, T. E. (1972, September). Dynamics of ice formation in the upper Niagara River. In International Symposium on the Role of Snow and Ice in Hydrology, Banff, Alberta: UNESCO-WMO-IHAS (Vol. 2, pp. p1296-1313).

Arkhipov, S. A., Isayeva, L. L., Bespaly, V. G., \& Glushkova, O. (1986). Glaciation of Siberia and north-east USSR. Quaternary Science Reviews, 5, 463-474.

Barreiro, M., Philander, G., Pacanowski, R., \& Fedorov, A. (2006). Simulations of warm tropical conditions with application to middle Pliocene atmospheres. Climate Dynamics, 26(4), 349-365.

Bartoli, G., Sarnthein, M., Weinelt, M., Erlenkeuser, H., Garbe-Schönberg, D., \& Lea, D. W. (2005). Final closure of Panama and the onset of northern hemisphere glaciation. Earth and Planetary Science Letters, 237(1), 33-44.

Boulton, G. S. (2006). Glaciers and their coupling with hydraulic and sedimentary processes. Glacier science and environmental change, 2-22.

Boyle,E. 12.740 Paleoceanography, Spring 2008. (Massachusetts Institute of Technology: MIT OpenCourseWare), http://ocw.mit.edu (Accessed 26 Jul, 2014).

Brierley, C. M., Fedorov, A. V., Liu, Z., Herbert, T. D., Lawrence, K. T., \& LaRiviere, J. P. (2009). Greatly expanded tropical warm pool and weakened Hadley circulation in the early Pliocene. Science, 323(5922), 1714-1718.

Briner, J. P., \& Kaufman, D. S. (2000). Late Pleistocene glaciation of the southwestern Ahklun mountains, Alaska. Quaternary Research, 53(1), 13-22.

Briner, J. P., \& Kaufman, D. S. (2008). Late Pleistocene mountain glaciation in Alaska: key chronologies. Journal of Quaternary Science, 23(6- 7), 659-670.

Caissie, B. E., Brigham- Grette, J., Lawrence, K. T., Herbert, T. D., \& Cook, M. S. (2010). Last Glacial Maximum to Holocene sea surface conditions at Umnak Plateau, Bering Sea, as inferred from diatom, alkenone, and stable isotope records. Paleoceanography, 25(1).

Cane, M. A., \& Molnar, P. (2001). Closing of the Indonesian seaway as a precursor to east African aridification around 3-4 million years ago. Nature, 411(6834), 157162. 
Clark, P. U., Archer, D., Pollard, D., Blum, J. D., Rial, J. A., Brovkin, V., ... \& Roy, M. (2006). The middle Pleistocene transition: characteristics, mechanisms, and implications for long-term changes in atmospheric pCO 2. Quaternary Science Reviews, 25(23), 3150-3184.

Conolly, J. R., \& Ewing, M. (1970). Ice-rafted detritus in northwest Pacific deep-sea sediments. Geological Society of America Memoirs, 126, 219-232.

Cook, M. S., Keigwin, L. D., \& Sancetta, C. A. (2005). The deglacial history of surface and intermediate water of the Bering Sea. Deep Sea Research Part II: Topical Studies in Oceanography, 52, 2163-2173.

Cooper, A. F., Barreiro, B. A., Kimbrough, D. L., \& Mattinson, J. M. (1987). Lamprophyre dike intrusion and the age of the Alpine fault, New Zealand. Geology, 15, 941-944.

Coxall, H. K., Wilson, P. A., Pälike, H., Lear, C. H., \& Backman, J. (2005). Rapid stepwise onset of Antarctic glaciation and deeper calcite compensation in the Pacific Ocean. Nature, 433(7021), 53-57.

Creager, J. S., \& Scholl, D. W. (1973). Initial reports of the Deep Sea Drilling Project, v. 19: Washington, DC, US Govt. Printing Office.

De Schepper, S., Gibbard, P. L., Salzmann, U., \& Ehlers, J. (2014). A global synthesis of the marine and terrestrial evidence for glaciation during the Pliocene Epoch. Earth-Science Reviews, 135, 83-102.

DeConto, R. M., \& Pollard, D. (2003). Rapid Cenozoic glaciation of Antarctica induced by declining atmospheric CO2. Nature, 421(6920), 245-249.

Dickinson, W. R., \& Suczek, C. A. (1979). Plate tectonics and sandstone compositions. Aapg Bulletin, 63, 2164-2182.

Dickinson, W. R., Beard, L. S., Brakenridge, G. R., Erjavec, J. L., Ferguson, R. C., Inman, K. F., ... \& Ryberg, P. T. (1983). Provenance of North American Phanerozoic sandstones in relation to tectonic setting. Geological Society of America Bulletin, 94(2), 222-235.

Dowsett, H. J., T. M. Cronin, P. Z. Poore, R. S. Thompson, R. C. Whatley, and A. M. Wood (1992), Micropaleontological evidence for increased meridional heattransport in the North Atlantic Ocean during the Pliocene, Science, 258, 11331135 .

Driscoll, N. W., \& Haug, G. H. (1998). A short circuit in thermohaline circulation: A cause for Northern Hemisphere glaciation?. Science, 282(5388), 436-438. 
Dunhill, G. (1998). Comparison of sea-ice rafted debris; grain size, surface features, and grain shape (No. 98-367). US Geological Survey,.

Eldrett, J. S., Harding, I. C., Wilson, P. A., Butler, E., \& Roberts, A. P. (2007). Continental ice in Greenland during the Eocene and Oligocene. Nature, 446(7132), 176-179.

Expedition 323 Scientists, (2010), Bering Sea paleoceanography: Pliocene-Pleistocene paleoceanography and climate history of the Bering Sea: Integrated Ocean Drilling Program Preliminary Report 323, doi:10.2204/iodp.pr.323.2010

Fedorov, A. V., Dekens, P. S., McCarthy, M., Ravelo, A. C., Barreiro, M., Pacanowski, R. C., \& Philander, S. G. (2006). The Pliocene paradox (mechanisms for a permanent El Niño). Science, 312(5779), 1485-1489.

Fullam, T. J., Supko, P. R., Boyce, R. E., \& Stewart, R. J. (1973). Some aspects of late Cenozoic sedimentation in the Bering Sea and North Pacific Ocean. Initial Reports of the Deep Sea Drilling Project, 19, 887-896.

Glazovskii, A. F., \& Solomina, O. N. (1988). Dynamics of Glaciers on the Northern Slope of the Tekskei Ala-Too Ridge from Lichenometric Data. Mat. Glyatsiol. Issled, (62), 113-119.

Gornitz, V. (2009). Encyclopedia of paleoclimatology and ancient environments. Springer Science \& Business Media.

Greve, R., \& Blatter, H. (2009). Dynamics of ice sheets and glaciers. Springer Science \& Business Media.

Grobe, H. (1987). A simple method for the determination of ice-rafted debris in sediment cores. Polarforschung, 57(3), 123-126.

Haug, G. H., \& Tiedemann, R. (1998). Effect of the formation of the Isthmus of Panama on Atlantic Ocean thermohaline circulation. Nature, 393(6686), 673-676.

Haug, G. H., Sigman, D. M., Tiedemann, R., Pedersen, T. F., \& Sarnthein, M. (1999). Onset of permanent stratification in the subarctic Pacific Ocean. Nature, 401(6755), 779-782.

Haug, G. H., Tiedemann, R., Zahn, R., \& Ravelo, A. C. (2001). Role of Panama uplift on oceanic freshwater balance. Geology, 29(3), 207-210.

Haug, G. H., Ganopolski, A., Sigman, D. M., Rosell-Mele, A., Swann, G. E., Tiedemann, R., ... \& Eglinton, G. (2005). North Pacific seasonality and the glaciation of North America 2.7 million years ago. Nature, 433(7028), 821-825. 
Haywood, A. M., \& Valdes, P. J. (2004). Modelling Pliocene warmth: contribution of atmosphere, oceans and cryosphere. Earth and Planetary Science Letters, 218(3), 363-377.

Haywood, A. M., Dekens, P., Ravelo, A. C., \& Williams, M. (2005). Warmer tropics during the mid- Pliocene? Evidence from alkenone paleothermometry and a fully coupled ocean- atmosphere GCM. Geochemistry, Geophysics, Geosystems, 6(3).

Helland, P. E., \& Holmes, M. A. (1997). Surface textural analysis of quartz sand grains from ODP Site 918 off the southeast coast of Greenland suggests glaciation of southern Greenland at 11 Ma. Palaeogeography, Palaeoclimatology, Palaeoecology, 135(1), 109-121.

Hood, D. W. (1983). The Bering Sea.

Hönisch, B., Hemming, N. G., Archer, D., Siddall, M., \& McManus, J. F. (2009). Atmospheric carbon dioxide concentration across the mid-Pleistocene transition. Science, 324(5934), 1551-1554.

Horikawa, K., Martin, E. E., Basak, C., Onodera, J., Seki, O., Sakamoto, T., ... \& Kawamura, K. (2015). Pliocene cooling enhanced by flow of low-salinity Bering Sea water to the Arctic Ocean. Nature communications, 6.

Jansen, E., \& Veum, T. (1990). Evidence for two-step deglaciation and its impact on North Atlantic deep-water circulation. Nature, 343, 612-616.

Jansen, E. Raymo, M. Blum, P. et al. (1996). Proceedings Ocean Drilling Program Initial Reports. 162, College Station, TX (Ocean Drilling Program)

Katsuki, K., \& Takahashi, K. (2005). Diatoms as paleoenvironmental proxies for seasonal productivity, sea-ice and surface circulation in the Bering Sea during the late Quaternary. Deep Sea Research Part II: Topical Studies in Oceanography, 52(16), 2110-2130.

Keller, J., \& Merzkirch, W. (1990). Interaction of a normal shock wave with a compressible turbulent flow. Experiments in fluids, 8(5), 241-248.

Kennett, J. P., \& Thunell, R. C. (1975). Global increase in Quaternary explosive volcanism. Science, 187(4176), 497-502.

Kennett, J. P. (1977). Cenozoic evolution of Antarctic glaciation, the circum- Antarctic Ocean, and their impact on global paleoceanography. Journal of geophysical research, 82(27), 3843-3860.

Kent, D., D Opdyke, N., \& Ewing, M. (1971). Climate change in the North Pacific using 
ice-rafted detritus as a climatic indicator. Geological Society of America Bulletin, 82(10), 2741-2754.

Kim, S., Khim, B. K., Uchida, M., Itaki, T., \& Tada, R. (2011). Millennial-scale paleoceanographic events and implication for the intermediate-water ventilation in the northern slope area of the Bering Sea during the last 71kyrs. Global and Planetary Change, 79(1), 89-98.

Krinsley, D. H., \& Donahue, J. (1968). Environmental interpretation of sand grain surface textures by electron microscopy. Geological Society of America Bulletin, 79, 743-748.

Krinsley, D. H., \& Doornkamp, J. C. (1973). Atlas of quartz sand surface textures (Vol. 91). Cambridge: Cambridge University Press.

Krissek, L. A. (1989). Late Cenozoic records of ice-rafting at ODP Sites 642, 643, and 644, Norwegian Sea: onset, chronology, and characteristics of glacial/interglacial fluctuations. In Proceedings of the Ocean Drilling Project. Scientific Results (Vol. 104, pp. 61-69). Texas A\&M University College Station, TX.

Krissek, L. A. (1995). Late Cenozoic ice-rafting records from Leg 145 sites in the North Pacific: Late Miocene onset, late Pliocene intensification, and PliocenePleistocene events. In Proceedings of the Ocean Drilling Program. Scientific results (Vol. 145, pp. 179-194). Ocean Drilling Program.

Kwiek, P. B., \& Ravelo, A. C. (1999). Pacific Ocean intermediate and deep water circulation during the Pliocene. Palaeogeography, Palaeoclimatology, Palaeoecology, 154(3), 191-217.

Lisiecki, L. E., \& Raymo, M. E. (2005). A Pliocene- Pleistocene stack of 57 globally distributed benthic $\delta 180$ records. Paleoceanography, 20(1).

Lisitsyn, A.P., (1969). Recent sedimentation in the Bering Sea: Akademiya Nauk SSSR, Trudy Instituta Okeanologii: Jerusalem, Israel Program for Scientific Translation, $614 \mathrm{p}$.

Lisitsyn, A. P. (2002). Sea-ice and iceberg sedimentation in the ocean: recent and past. Berlin: Springer.

Lunt, D. J., Valdes, P. J., Haywood, A., \& Rutt, I. C. (2008). Closure of the Panama Seaway during the Pliocene: implications for climate and Northern Hemisphere glaciation. Climate Dynamics, 30(1), 1-18.

März, C., Schnetger, B., \& Brumsack, H. J. (2013). Nutrient leakage from the North Pacific to the Bering Sea (IODP Site U1341) following the onset of Northern 
Hemispheric Glaciation?. Paleoceanography, 28(1), 68-78.

Maslin, M. A., Haug, G. H., Sarnthein, M., Tiedemann, R., Erlenkeuser, H., \& Stax, R. (1995). 21. Northwest Pacific Site 883: The Initiation of Northern Hemisphere Glaciation In Proceedings of the Ocean Drilling Program. Scientific results (Vol. 145, pp. 179-194). Ocean Drilling Program.

Maslin, M. A., Haug, G. H., Sarnthein, M., \& Tiedemann, R. (1996). The progressive intensification of northern hemisphere glaciation as seen from the North Pacific. Geologische Rundschau, 85, 452-465.

Maslin, M. A., Li, X. S., Loutre, M. F., \& Berger, A. (1998). The contribution of orbital forcing to the progressive intensification of Northern Hemisphere glaciation. Quaternary Science Reviews, 17(4-5), 411-426.

McCormick, M. J., Barnes, P. W., \& Reimnitz, E. (1993). Studies of sediment transport by Beaufort Gyre pack ice, 1992; sediment, ice, \& water data (No. 93-19). US Geological Survey,.

McKelvey, B. C., Chen, W., \& Arculus, R. J. (1995). Provenance of Pliocene-Pleistocene ice rafted debris, Leg 145. In Proceedings of the Ocean Drilling Program. Scientific results (Vol. 145, pp. 179-194). Ocean Drilling Program.

Molén, M. O. (2014). A simple method to classify diamicts by scanning electron microscope from surface microtextures. Sedimentology, 61, 2020-2041.

Molina, B. (2004). Glossary of Glacier Terminology: A glossary providing the vocabulary necessary to understand the modern glacier environment. US Geological Survey.

Molnar, P., \& Cane, M. A. (2002). El Niño's tropical climate and teleconnections as a blueprint for pre- Ice Age climates. Paleoceanography, 17(2), 11-1.

Molnar, P., \& Huybers, P. (2007). Tropical cooling and the onset of North American glaciation.

Moran, K., Backman, J., Brinkhuis, H., Clemens, S. C., Cronin, T., Dickens, G. R., ... \& Kaminski, M. (2006). The Cenozoic palaeoenvironment of the Arctic Ccean. Nature, 441(7093), 601-605.

Niebauer, H. J., Bond, N. A., Yakunin, L. P., \& Plotnikov, V. V. (1999). An update on the climatology and sea ice of the Bering Sea. Dynamics of the Bering Sea, 29-60.

Nürnberg, D., Wollenburg, I., Dethleff, D., Eicken, H., Kassens, H., Letzig, T., ... \& Thiede, J. (1994). Sediments in Arctic sea ice: implications for entrainment, 
transport and release. Marine Geology, 119(3), 185-214.

Okazaki, Y., Takahashi, K., Asahi, H., Katsuki, K., Hori, J., Yasuda, H., ... \& Tokuyama, H. (2005). Productivity changes in the Bering Sea during the late Quaternary. Deep Sea Research Part II: Topical Studies in Oceanography, 52(16), 2150-2162.

Pettijohn, F. J., Potter, P. E., \& Siever, R. (2012). Sand and sandstone. Springer Science $\&$ Business Media.

Philander, S. G., \& Fedorov, A. V. (2003). Role of tropics in changing the response to Milankovich forcing some three million years ago. Paleoceanography, 18(2).

Piper, D. J. W., \& Brisco, C. D. (1975). Deep-water continental-margin sedimentation, DSDP Leg 28, Antarctica. Initial Reports of the Deep Sea Drilling Project, 28, 727-755.

Plafker, G., \& Berg, H. C. (Eds.). (1994). The geology of Alaska.

Prueher, L. M., \& Rea, D. K. (2001). Volcanic triggering of late Pliocene glaciation: Evidence from the flux of volcanic glass and ice-rafted debris to the North Pacific Ocean. Palaeogeography, Palaeoclimatology, Palaeoecology, 173(3), 215-230.

Ravelo, A. C., \& Andreasen, D. H. (2000). Enhanced circulation during a warm period. Geophysical Research Letters, 27, 1001-1004.

Ravelo, A. C., Andreasen, D. H., Lyle, M., Lyle, A. O., \& Wara, M. W. (2004). Regional climate shifts caused by gradual global cooling in the Pliocene epoch. Nature, 429(6989), 263-267.

Ravelo, A. C., Dekens, P. S., \& McCarthy, M. (2006). Evidence for El Niño-like conditions during the Pliocene. GSA Today, 16(3), 4.

Raymo, M. E., Ruddiman, W. F., \& Froelich, P. N. (1988). Influence of late Cenozoic mountain building on ocean geochemical cycles. Geology, 16, 649-653.

Raymo, M. E., \& Ruddiman, W. F. (1992). Tectonic forcing of late Cenozoic climate. Nature, 359(6391), 117-122.

Raymo, M. E., and G. H. Rau (1992), Plio-Pleistocene atmospheric CO2 levels inferred from POM d13C at DSDP Site 607, Eos Trans. AGU, Fall Meeting Supplementary, 73(43), 95.

Raymo, M. E. (1994). The initiation of Northern Hemisphere glaciation. Annual Review of Earth and Planetary Sciences, 22, 353-383. 
Raymo, M. E., Grant, B., Horowitz, M., \& Rau, G. H. (1996). Mid-Pliocene warmth: stronger greenhouse and stronger conveyor. Marine Micropaleontology, 27(1), 313-326.

Raymo, M. E., Lisiecki, L. E., \& Nisancioglu, K. H. (2006). Plio-Pleistocene ice volume, Antarctic climate, and the global $\delta 18 \mathrm{O}$ record. Science, 313(5786), 492-495.

Raymo, M. E., \& Huybers, P. (2008). Unlocking the mysteries of the ice ages. Nature, 451(7176), 284-285.

Rea, D. K., \& Schrader, H. (1985). Late Pliocene onset of glaciation: ice-rafting and diatom stratigraphy of North Pacific DSDP cores. Palaeogeography, palaeoclimatology, palaeoecology, 49(3), 313-325.

Rea, D.K., Basov, I.A., and Krissek, L.A., and the Leg 145 Scientific Party, (1993), Proceedings of the Ocean Drilling Program, Initial reports, 145: College Station, Texas, Ocean Drilling Program.

Rea, D. K., Basov, I. A., \& Krissek, L. A. (1995). Scientific results of drilling the North Pacific Transect. In Proceedings of the Ocean Drilling Program. Scientific Results (Vol. 145, pp. 577-596). Ocean Drilling Program.

Reece, R. S., Gulick, S. P., Horton, B. K., Christeson, G. L., \& Worthington, L. L. (2011). Tectonic and climatic influence on the evolution of the Surveyor Fan and Channel system, Gulf of Alaska. Geosphere, 7, 830-844.

Reimnitz, E., \& Bruder, K. F. (1972). River discharge into an ice-covered ocean and related sediment dispersal, Beaufort Sea, coast of Alaska. Geological Society of America Bulletin, 83(3), 861-866.

Reimnitz, E., \& Maurer, D. K. (1979). Eolian sand deflation-A cause for gravel barrier islands in arctic Alaska?. Geology, 7(10), 507-510.

Reimnitz, E., \& Kempema, E. W. (1987). Field observations of slush ice generated during freeze-up in Arctic coastal waters. Marine Geology, 77(3), 219-231.

Reimnitz, E., Kempema, E. W., \& Barnes, P. W. (1987). Anchor ice, seabed freezing, and sediment dynamics in shallow Arctic seas. Journal of Geophysical Research: Oceans (1978-2012), 92(C13), 14671-14678.

Reimnitz, E., \& Kempema, E. W. (1988). Ice rafting: an indication of glaciation?. Journal of Glaciology, 34, 254-255.

Reimnitz, E., Barnes, P.W. and Kempema, E.W., (1990). Polar processes in "calm" ice covered waters. 19th Arctic Workshop, Instaar, University of Colorado, 67. 
Reimnitz, E., \& Saarso, M. (1991). Studies of sediment transport by ice. In Die Expedition Arktis VII-I, mit FS “Polarstern" 1990 (Vol. 80, pp. 44-50).

Reimnitz, E., Marincovich Jr, L., McCormick, M., \& Briggs, W. M. (1992). Suspension freezing of bottom sediment and biota in the Northwest Passage and implications for Arctic Ocean sedimentation. Canadian Journal of Earth Sciences, 29, 693703.

Reimnitz, E., McCormick, M., McDougall, K., \& Brouwers, E. (1993). Sediment export by ice rafting from a coastal polynya, Arctic Alaska, USA. Arctic and Alpine Research, 83-98.

Rind, D., \& Chandler, M. (1991). Increased ocean heat transports and warmer climate. Journal of Geophysical Research: Atmospheres (1984-2012), 96, 7437-7461.

Robe, R. Q. (2012). 4 Iceberg Drift and Deterioration. Dynamics of snow and ice masses, 211.

Ruddiman, W. F. (1977). Late Quaternary deposition of ice-rafted sand in the subpolar North Atlantic (lat 40 to 65 N). Geological Society of America Bulletin, 88, 18131827.

Ruddiman, W. F., McIntyre, A., Niebler-Hunt, V., \& Durazzi, J. T. (1980). Oceanic evidence for the mechanism of rapid northern hemisphere glaciation. Quaternary Research, 13(1), 33-64.

Shackleton, N. J., Le, J., Mix, A., \& Hall, M. A. (1992). Carbon isotope records from Pacific surface waters and atmospheric carbon dioxide. Quaternary Science Reviews, 11(4), 387-400.

Shorttle, O., Tripati, A., Eagle, R. A., Dawber, C., Morton, A., Dowdeswell, J., ... \& Khadun, E. (2007, December). Evidence for Northern Hemisphere Glaciation Back to 44 Ma From Ice-Rafted Debris in the Greenland Sea. In AGU Fall Meeting Abstracts (Vol. 1, p. 0085).

Smith, L. M., Miller, G. H., Otto-Bliesner, B., \& Shin, S. I. (2003). Sensitivity of the Northern Hemisphere climate system to extreme changes in Holocene Arctic sea ice. Quaternary Science Reviews, 22(5), 645-658.

St John, K. E., \& Krissek, L. A. (1999). Regional patterns of Pleistocene ice- rafted debris flux in the North Pacific. Paleoceanography, 14, 653-662.

Stewart, G. W. (1979). The effects of rounding error on an algorithm for downdating a Cholesky factorization. IMA Journal of Applied Mathematics, 23(2), 203-213. 
Stewart, R. B., \& Neall, V. E. (1984). Chronology of palaeoclimatic change at the end of the last glaciation.

Takahashi, K. (1998). The Bering and Okhotsk Seas: modern and past paleoceanographic changes and gateway impact. Journal of Asian Earth Sciences, 16(1), 49-58.

Takahashi, K. (2005). The Bering Sea and paleoceanography. Deep Sea Research Part II: Topical Studies in Oceanography, 52(16), 2080-2091.

Tripati, A. K., Eagle, R. A., Morton, A., Dowdeswell, J. A., Atkinson, K. L., Bahé, Y., ... \& Thanabalasundaram, L. (2008). Evidence for glaciation in the Northern Hemisphere back to $44 \mathrm{Ma}$ from ice-rafted debris in the Greenland Sea. Earth and Planetary Science Letters, 265(1), 112-122.

Van Der Burgh, J., Visscher, H., Dilcher, D. L., \& Kürschner, W. M. (1993).

Paleoatmospheric signatures in Neogene fossil leaves. Science, 260, 1788-1790.

VanLaningham, S., Pisias, N. G., Duncan, R. A., \& Clift, P. D. (2009). Glacialinterglacial sediment transport to the Meiji Drift, northwest Pacific Ocean: Evidence for timing of Beringian outwashing. Earth and Planetary Science Letters, 277(1), 64-72.

Wanke, M., Portnyagin, M., Hoernle, K., Werner, R., Hauff, F., van den Bogaard, P., \& Garbe-Schönberg, D. (2012). Bowers Ridge (Bering Sea): An Oligocene-Early Miocene island arc. Geology, 40, 687-690.

Wara, M. W., Ravelo, A. C., \& Delaney, M. L. (2005). Permanent El Niño-like conditions during the Pliocene warm period. Science, 309, 758-761.

Weltje, G. J., \& von Eynatten, H. (2004). Quantitative provenance analysis of sediments: review and outlook. Sedimentary Geology, 171(1), 1-11.

Wolf-Welling, T. C., Cremer, M., O'CONNELL, S., Winkler, A., \& Thiede, J. (1996). Cenozoic Arctic Gateway paleoclimate variability: indications from changes in coarse-fraction composition. In Proceedings of the Ocean Drilling Program. Scientific Results (Vol. 151, pp. 515-567). Ocean Drilling Program.

Zachos, J.C., Pagani, M., Sloan, L.C., Thomas, E., Billups, K., (2001). Trends, rhythms, and aberrations in global climate 65 Ma to present. Science, 292, 686-693 